\title{
Inhibition of Vascular Smooth Muscle and Cancer Cell Proliferation by New VEGFR Inhibitors and Their Immunomodulator Effect: Design, Synthesis, and Biological Evaluation
}

\author{
Feng Ran, ${ }^{1}$ Wendong Li, ${ }^{1}$ Yi Qin, ${ }^{1}$ Tong Yu, ${ }^{1}$ Zhao Liu, ${ }^{1}$ Min Zhou, ${ }^{1}$ Cheng Liu, ${ }^{1}$ Tong Qiao, \\ Xiaoqiang Li $\odot,{ }^{1}$ Reda G. Yousef, ${ }^{2}$ Ibrahim H. Eissa $\oplus^{2},{ }^{2}$ and Mohamed M. Khalifa ${ }^{2}$ \\ ${ }^{1}$ Department of Vascular Surgery, Nanjing Drum Tower Hospital Affiliated to Nanjing University Medical School, \\ Nanjing 210008, China \\ ${ }^{2}$ Pharmaceutical Medicinal Chemistry \& Drug Design Department, Faculty of Pharmacy (Boys), Al-Azhar University, \\ Cairo 11884, Egypt \\ Correspondence should be addressed to Xiaoqiang Li; lixiaoqiang_dt@sina.com
}

Received 11 June 2021; Accepted 16 September 2021; Published 28 October 2021

Academic Editor: Alessandra Durazzo

Copyright (c) 2021 Feng Ran et al. This is an open access article distributed under the Creative Commons Attribution License, which permits unrestricted use, distribution, and reproduction in any medium, provided the original work is properly cited.

\begin{abstract}
Abnormal vascular smooth muscle cell (VSMC) proliferation has an important role in the pathogenesis of both atherosclerosis restenosis and hypertension. Vascular endothelial growth factor (VEGF) has been shown to stimulate VSMC proliferation. In addition, angiogenesis is one of the hallmarks of cancerous growth. VEGF is the key modulator for the initial stages of angiogenesis that acts through the endothelial-specific receptor tyrosine kinases (VEGFRs). VEGFR-2 blockage is a good approach for suppression of angiogenesis. In order to discover novel VEGFR-2 TK inhibitors, we have designed and synthesized three new series of pyridine-containing compounds. The new compounds were all screened against a panel of three cell lines (HepG-2, HCT-116, and MCF-7). Promising results encouraged us to additionally evaluate the most active members for their in vitro VEGFR-2 inhibitory effect. Compound $7 \mathrm{a}$, which is the most potent candidate, revealed a significant increase in caspase- 3 level by 7.80 -fold when compared to the control. In addition, Bax and Bcl-2 concentration levels showed an increase in the proapoptotic protein Bax $(261.4 \mathrm{Pg} / \mathrm{ml})$ and a decrease of the antiapoptotic protein Bcl-2 $(1.25 \mathrm{Pg} / \mathrm{ml})$ compared to the untreated cells. Furthermore, compound $7 \mathrm{a}$ arrested the cell cycle in the G2/M phase with induction of apoptosis. The immunomodulatory effect of compound $7 \mathrm{a}$, the most active member, showed a reduction in TNF- $\alpha$ by $87 \%$. Also, compound 7 a caused a potent inhibitory effect on smooth muscle proliferation. Docking studies were also performed to get better insights into the possible binding mode of the target compounds with VEGFR-2 active sites.
\end{abstract}

\section{Introduction}

Smooth muscles are located in many organs of the body. It performs many biological roles such as digestion and nutrient collection in the stomach and intestines. In the urinary system, it participates in toxin clearance and electrolyte balance. Also, it plays a critical role in the regulation of blood pressure and tissue oxygenation in arteries and veins. These important roles enable the body to maintain its most basic functions [1].
Abnormal vascular smooth muscle cell (VSMC) proliferation is thought to play an important role in the pathogenesis of both atherosclerosis restenosis and hypertension $[2,3]$. Many growth factors and cytokines have been shown to stimulate VSMC proliferation such as vascular endothelial growth factor (VEGF) $[4,5]$, platelet-derived growth factors (PDGF) [6], basic fibroblast growth factor (bFGF) [7], tumor necrosis factor- $\alpha$ (TNF- $\alpha$ ) [8], and interleukin-1 [9]. VEGF is overexpressed by VSMC in the intima of atherosclerotic human coronary arteries [10]. 
One of the hallmarks of cancerous growth is angiogenesis, the process of development of new capillaries from preexisting blood vessels [11-13]. The newly formed blood vessels supply oxygen and nutrients to the tumor cells that augments their growth and metastasis [14]. Tumors that lack a sufficient vasculature become necrotic or apoptotic and cannot grow beyond a limited size [15]. Thus, identifying new antiangiogenic molecules is still one of the main strategies for cancer treatment.

Regarding the molecular basis of angiogenesis, vascular endothelial growth factor (VEGF) is the key modulator for the initial stages of angiogenesis that acts through the endothelial-specific receptor tyrosine kinases (VEGFRs) [16]. VEGF has been proven to play pivotal roles in almost all aspects of cellular physiology [17]. Downregulation of kinase activity has been involved in many pathological cases ranging from neuronal complaints to cellular transformation in leukemias [18]. Over a quarter of all pharmaceutical drugs is currently estimated to target protein kinases [19], an assessment that encourages an ambitious search for discovery of new chemical scaffolds that have the potential to become drugs. VEGF is secreted by tumors and motivates a mitogenic response via its binding to one of three tyrosine kinase receptors (VEGFR 1-3) on nearby endothelial cells [20].

Among the redundancy in function and ligand receptor interactions, VEGFR-2 is considered the main receptor involved in mediating the permeability and in initiating cascades of transduction signals in response to interaction with VEGF [20]. Therefore, hindering this signaling pathway should block angiogenesis with subsequent starvation and reduction of tumor growth $[21,22]$.

Analyzing the VEGFR-2 kinase domain revealed that it comprises of a bilobed structure with Mg-ATP placed in a deep cleft located between the $\mathrm{N}$ - and C-terminal lobes [23]. Most of the historically developed kinase inhibitors (type I) target the ATP binding site (the active conformation) in a way that is almost identical to that of ATP [24]. Type I kinase inhibitors bind to the ATP binding site via development of hydrogen bonds to the kinase "hinge" residues in addition to hydrophobic interactions in and around the region occupied by the adenine ring of ATP [25]. Recently, a second class of tyrosine kinase inhibitors (type II) was identified [26]. This type binds not only to ATP binding site but also to an adjacent hydrophobic pocket created by the activation loop [27]. This pocket contains the conserved DFG motif. Type II inhibitors use also the ATP binding site in a similar way to type I, but they further interact with the DFG residues through unique hydrogen bonding and hydrophobic interactions [27]. Type II kinase inhibitors were proven to possess higher efficacy and selectivity compared to type I inhibitors.

In the past two decades, several patents and researches reported the discovery and design of numerous new type II kinase inhibitors that have the ability to form extensive hydrophobic and hydrogen bonding interactions with both the adenine and allosteric binding site [13, 16, 26, 28-31]. Although all VEGFR-2 tyrosine kinase inhibitors target VEGF signaling, they are structurally varied and differ in pharmacological efficacy and clinical performance.
On the other side, many antiangiogenic drugs targeting the VEGF/VEGFR pathway appear to be capable of modulating immune responses. Such immunomodulatory activity has a positive effect in cancer treatment; however, it has a harmful impact in some cases [32]. In some cancer patients, there is an increase in the level of MDSCF which interferes with antigen presenting cells (APC) and effector T-cell functions. Hence, it is necessary to reduce these cells during the clinical treatment using immunotherapeutic modalities [33-35]. Sunitinib, which is one of the VEGFRIs, was reported to have a potential to modulate antitumor immunity by reversing MDSC accumulation [36, 37]. Additionally, the treatment using sunitinib can reduce expression of interleukin-10, tumor growth factor-beta, and Foxp3. In the same time, it can enhance expression of Th1 cytokine interferon-gamma (IFN- $\gamma$ ) [37]. Imatinib, as another example of VEGFRI, was proven to exert significant immunomodulatory changes in APC and T cells during clinical treatment of cancer patients [32].

The neovascularization (angiogenesis) process is the initial step for cancer development and metastasis [38]. One of the key elements in such a step is vascular smooth muscle cells (SMCs) which consist of the majority of the cells forming the wall of blood vessels. It is well known that SMCs have a critical contribution in neovascularization and transformation of the blood vessels $[2,39]$. It was confirmed that VEGF isoforms are involved in the normal formation of SMCs surrounded by arteries [5]. Additionally, the in vitro angiogenesis assay described by Sini et al. confirmed that the epidermal growth factor can potentiate the SMCs to release VEGF, leading to a dramatic development in angiogenesis. Such process can be blocked by VEGFIs [40]. Thus, the class of VEGFIs may be a promising approach that can inhibit SMC proliferation and consequently tumor growth.

The previous findings encouraged our team to design a novel series of VEGFR-2 tyrosine kinase inhibitors that could tackle both tumor angiogenesis and SMC proliferation in addition to enhancement of the immune responses of the metastatic cells.

1.1. Rationale of Molecular Design. The main target of our work is the discovery of new VEGFR-2 inhibitors. These new compounds should comprise the essential pharmacophoric feature of the reported and FDA-approved VEGFR2 inhibitors. The new compounds were assessed for their inhibitory effect against vascular smooth muscle and cancer cell proliferation. As well, their potential activity against VEGFR-2 was also investigated. In order to prove the immunomodulatory action of the synthesized compounds, different mediators such as caspase-3, BAX, BCl-2, and TNF- $\alpha$ were investigated in vitro on HepG-2 cells after application of the most active compounds.

Over the last few years, much efforts have been made by our research members aimed at developing drugs and optimize the effects of VEGFR-2 tyrosine kinase inhibitors via using the X-ray crystal structures of VEGFR-2 protein with various ligands $[13,16-18,31,41]$. Examination of the binding features of known type II inhibitors led us to a conclusion regarding the main pharmacophoric requirements 


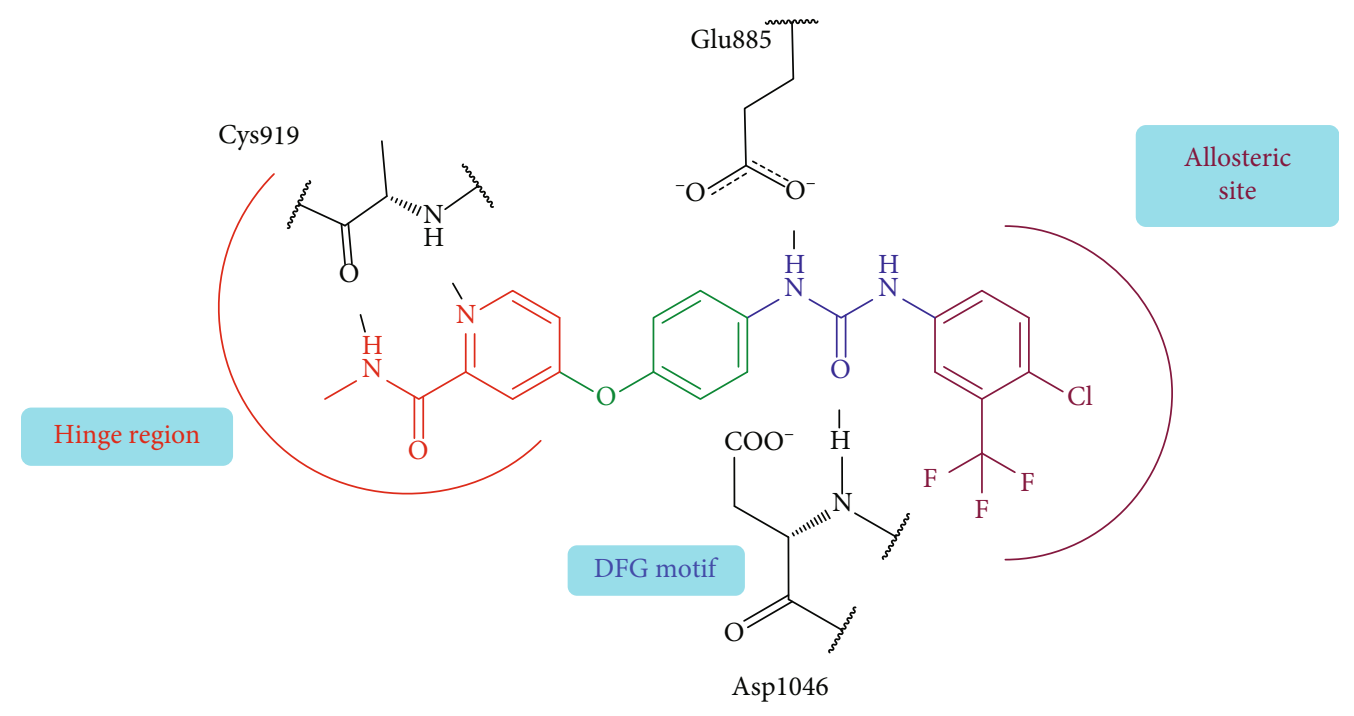

FIGURE 1: The essential pharmacophoric features of VEGFR-2 inhibitors. Red: hinge head; green: linker; blue: hydrogen-bonding moiety; maroon: hydrophobic tail.

needed for the generation of new members that strongly hinder the action of VEGF on VEGFR-2 receptors. These requirements were demonstrated to be four main moieties. The first one is a "hinge-binding" head segment which is typically a flat heteroaromatic ring with at least one $\mathrm{H}$ bond acceptor that allows the compound to bind to the ATP pocket via a hydrogen bond with the backbone $\mathrm{NH}$ of Cys919 residue. The second requirement is a 3-6 chemical bond length "linker" or "spacer." The linker is either a rigid aromatic ring system or a highly flexible aliphatic chain. Its role is to traverse the kinase gatekeeper residues linking the hinge-binding segment with the hydrogen-bonding moiety. The "hydrogen-bonding moiety" is the third pharmacophoric feature needed for the design of VEGFR-2 inhibitors. It interacts via hydrogen bonding with Glu885 and/or Asp1046 residues in the DFG motif of the enzyme. The fourth part is the "tail" segment that consists of a hydrophobic moiety. It occupies the allosteric hydrophobic region binding through different hydrophobic interactions (Figure 1).

The previous investigation gave us the opportunities to design novel VEGFR-2 inhibitors with different spacers, hydrogen-bonding moieties, and/or various substituents around the terminal hydrophobic ring. Sorafenib (Figure 1) was used as a lead compound. Thus, three main scaffolds were designed and biologically evaluated for their VEGFR2 inhibitory effects. Similarly as sorafenib, the hingebinding head of all scaffolds was fixed to be a pyridine ring.

Scaffolds 1 and 2 were developed by structure optimization of sorafenib through increasing the length of the linker portion to be a phenyl carbamoyl group instead of the sorafenib phenoxy group. Another modification was made via replacement of the sorafenib urea HBA/HBD portion either by an amide moiety (scaffold 1) or a hydrazone moiety (scaffold 2). The hydrophobic tail was also modified to have an aliphatic structure 10 or aromatic moiety with different substitutions 5, 6, 7a-l, and 11a-h (Figure 2).

On the other side, many published articles reported that an oxadiazole moiety plays a vital role in the antiproliferative activity when it is used as a spacer in numerous synthetic molecules to join different anticancer scaffolds [42-44]. Consequently, linking the pyridine ring, via the oxadiazole moiety, to different hydrophobic tails bearing an amide group afforded the potent scaffold 3 VEGFR-2 inhibitors 18a-c (Figure 2).

The wide variety of modifications allowed us to examine the SAR of the designed compounds as effective antiproliferative agents with potential VEGFR-2 inhibitory effects. To confirm such design, silicomolecular docking studies of the synthesized compounds were performed against the prospective biological target (VEGFR-2).

\section{Results and Discussion}

2.1. Chemistry. Nicotinamide derivatives $5,6,7 \mathrm{a}-\mathrm{l}, 10$, and $11 \mathrm{a}-\mathrm{h}$ were prepared following the reactions shown in Schemes 1 and 2. Compounds 5, 6, and 7a-1 bearing various carbamoyl groups were synthesized starting from the commercially available nicotinic acid 1 . Compound 1 was chlorinated using thionyl chloride in dichloroethane to afford nicotinoyl chloride 2 [45]. $\mathrm{S}_{\mathrm{N}} \mathrm{Ar}$ displacement reaction of 2 with 4-aminobenzoic acid in the presence of TEA gave 4-(nicotinamido)benzoic acid 3. Subsequently, compound 3 was treated with thionyl chloride in dichloroethane to produce compound 4 in $85 \%$ yield. Treating compound 4 with cyclohexylamine, benzylamine, and different aniline derivatives in acetonitrile yielded the corresponding targeted compounds 5, 6, and 7a-1, respectively. The structures of compounds 5,6 , and $7 \mathrm{a}-\mathrm{l}$ were confirmed by ${ }^{1} \mathrm{H}$ NMR, which showed the presence of a new singlet signal attributed to a $\mathrm{NH}$ proton at a range of $\delta 9.13$ to $10.76 \mathrm{ppm}$ (Scheme 1).

Compound 2, moreover, underwent another $\mathrm{S}_{\mathrm{N}} \mathrm{Ar}$ displacement route using ethyl 4-aminobenzoate with a catalytic amount of TEA resulting in synthesis of ethyl 4(nicotinamido)benzoate 8 as white crystals [46]. The reflux of 8 with hydrazine hydrate in boiling ethanol for $12 \mathrm{~h}$ 


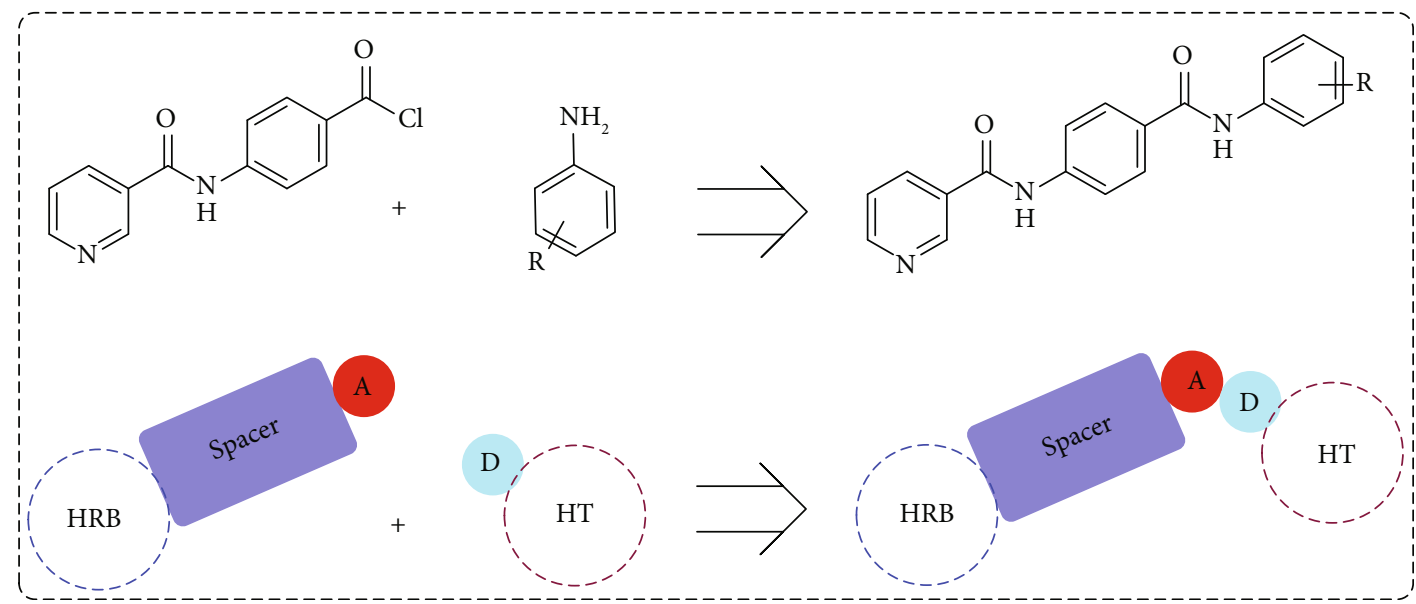

(a)

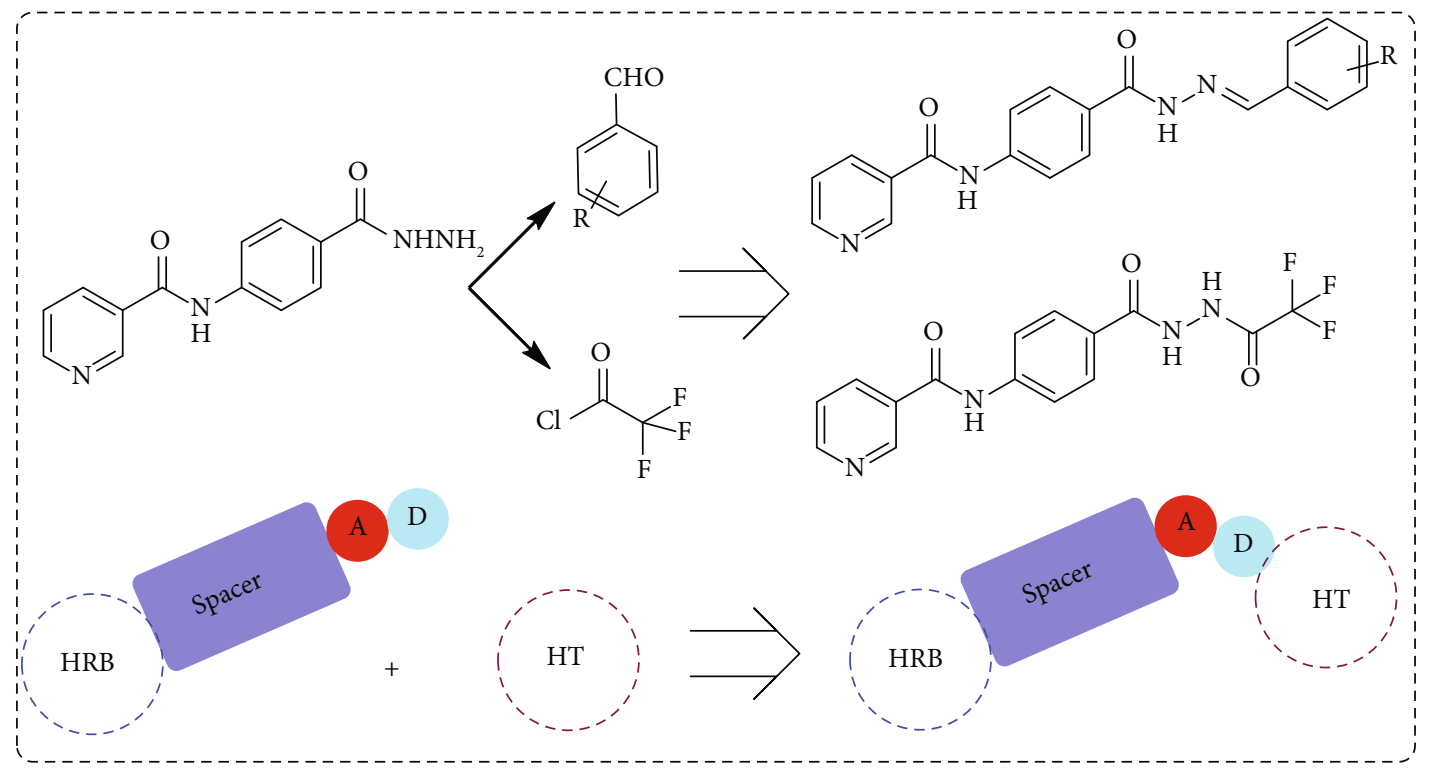

(b)

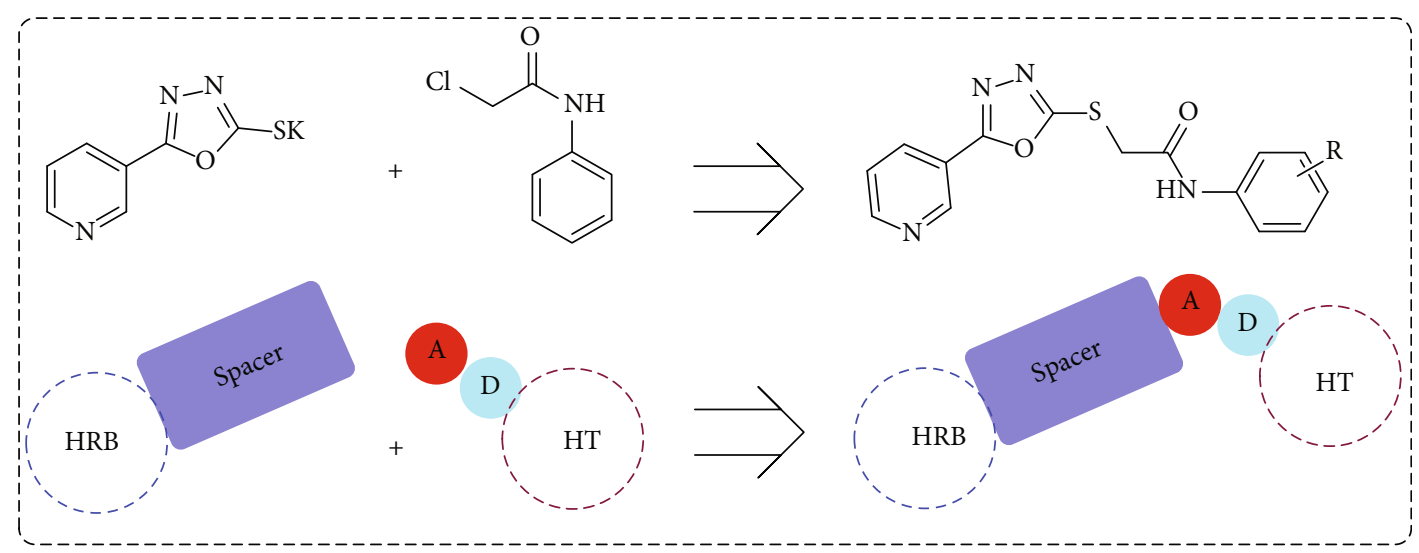

(c)

FIGURE 2: Design of the newly proposed VEGFR-2 inhibitors. A: hydrogen bond acceptor; D: hydrogen bond donor; HRB: hinge-region binding; HT: hydrophobic tail.

yielded $\quad \mathrm{N}$-(4-(hydrazinecarbonyl)phenyl)nicotinamide 9 [47]. The condensation of 9 with trifluoroacetic anhydride (TFAA) in DCM at room temperature afforded compound
10. Furthermore, a nucleophilic addition reaction was performed through the reaction of compound 9 with different benzaldehyde derivatives in the presence of a catalytic 


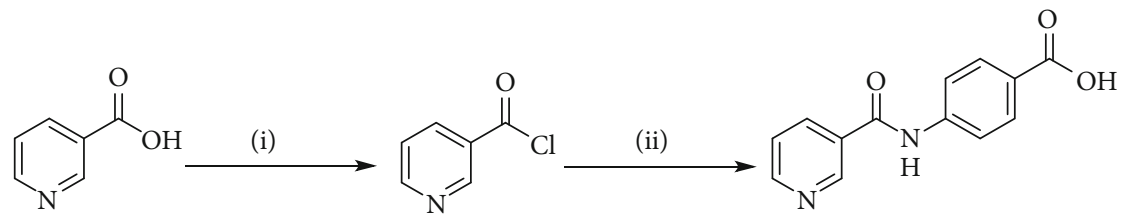

$(1)$<smiles>O=C(Nc1ccc(C(=O)NC2CCCCC2)cc1)c1cccnc1</smiles>

(2)

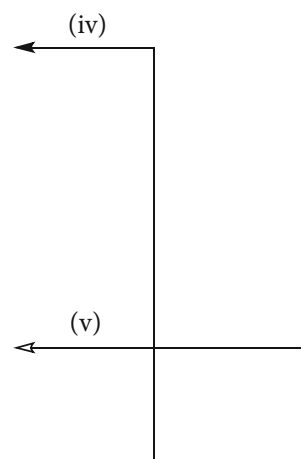<smiles>[3H][13CH3]</smiles>

(3)<smiles>O=C(Cl)c1ccc(NC(=O)c2cccnc2)cc1</smiles>

(6)

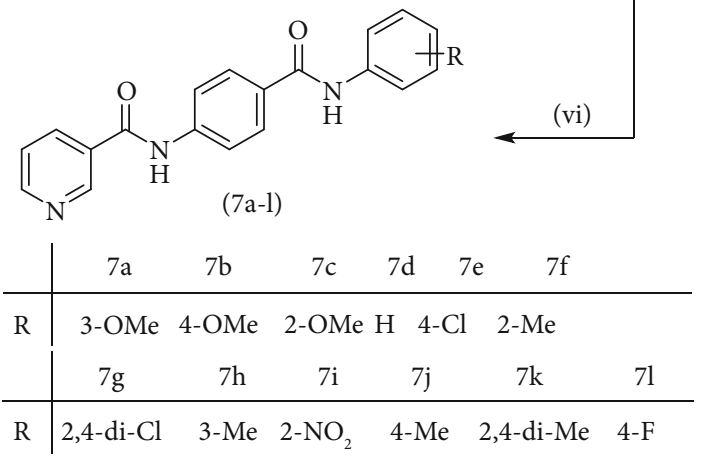

Scheme 1: General procedure for the synthesis of target compounds 5, 6, and 7a-1. Reagents and conditions: (i) thionyl chloride (SOCl ${ }_{2}$ ), dicloroethane, reflux, $2 \mathrm{~h}$; (ii) 4-aminibenzoic acid, triethylamine (TEA), acetonitrile, stirring, rt; (iii) thionyl chloride ( $\mathrm{SOCl}_{2}$ ), dichloroethane, reflux, $2 \mathrm{~h}$; (iv) cyclohexylamine, treithylamine (TEA), acetonitrile, reflux, $2 \mathrm{~h}$; (v) benzylamine, treithylamine (TEA), acetonitrile, reflux, $2 \mathrm{~h}$; (vi) app. amine, treithylamine (TEA), acetonitrile, reflux, $2 \mathrm{~h}$.

amount of glacial acetic acid to give the designed derivatives 11a-h. ${ }^{1} \mathrm{H}$ NMR of $11 \mathrm{a}-\mathrm{h}$ exhibited the disappearance of the characteristic $\mathrm{NH}_{2}$ signal of 9 and the appearance of a new benzylidene proton signal at $\delta$ values ranging from 8.34 to 8.89 ppm (Scheme 2).

On the other side, the employed synthetic pathway used for the preparation of the pyridinyl derivatives $18 \mathrm{a}-\mathrm{c}$ was outlined in Scheme 3. Scheme 3 began with the esterification of nicotinic acid 1 using methyl alcohol and sulfuric acid to afford methyl nicotinate 12 in a good yield. Compound 12 was then refluxed with hydrazine hydrate in ethanol to give nicotinohydrazide 13 . A cyclization reaction was efficiently carried out via treatment of 13 with carbon disulfide in alcoholic potassium hydroxide followed by neutralization with $\mathrm{HCl}$ yielding 5-(pyridin-3-yl)-1,3,4-oxadiazole-2-thiol 14. A subsequent reflux of 14 with potassium hydroxide in absolute ethanol afforded the potassium salt 15 . The later salt was then reacted with different acetanilide derivatives $17 \mathrm{a}-\mathrm{c}$, formed via the reaction of different amines $16 \mathrm{a}-\mathrm{c}$ with chloroacetylchloride, to produce the corresponding final compounds $18 \mathrm{a}-\mathrm{c}$. IR of $18 \mathrm{a}-\mathrm{c}$ were characterized by the appearance of carbonyl absorption bands at $1635-1647 \mathrm{~cm}^{-1}$ (Scheme 3).

\subsection{Biological Evaluation}

2.2.1. In Vitro Antiproliferative Activity against MCF-7, HepG-2, and HCT-116. The in vitro antiproliferative activities of the newly synthesized compounds were evaluated against a panel of three human tumor cell lines, namely, breast cancer (MCF-7), hepatocellular carcinoma (HepG2), and colorectal carcinoma (HCT-116) using the standard MTT method. The tested cell lines were selected depending on their VEGF overexpression. Sorafenib, the lead drug, was coassayed as a positive control. The cytotoxicity results are presented in Table 1.

Regarding the $\mathrm{N}$-[4-(substituted carbamoyl)phenyl]nicotinamide 5, 6, and 7a-1 series, it was noticed that the cytotoxicity $\mathrm{IC}_{50}$ of these members ranged from 1.25 to $42.10 \mu \mathrm{M}$ (MCF-7), 1.05 to $31.45 \mu \mathrm{M}$ (HepG-2), and 1.46 to $31.70 \mu \mathrm{M}$ (HCT-116) in comparison to the reference drug, sorafenib, with $\mathrm{IC}_{50}$ values of 4.32 (MCF-7), 3.76 (HepG-2), and 


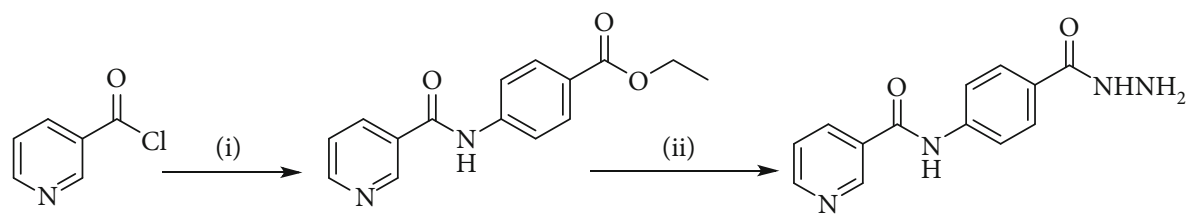

(2)

(8)

(iv)<smiles>[R]c1ccc(/C=N/NC(=O)c2ccc(NC(=O)c3cccnc3)cc2)cc1</smiles>

\begin{tabular}{l|ccccc} 
& $11 \mathrm{a}$ & $11 \mathrm{~b}$ & $11 \mathrm{c}$ & $11 \mathrm{~d}$ & \\
\hline $\mathrm{R}$ & $4-\mathrm{F}$ & $\mathrm{H}$ & $4-\mathrm{NO}_{2}$ & $4-\mathrm{OMe}$ & \\
& $11 \mathrm{e}$ & & $11 \mathrm{f}$ & $11 \mathrm{~g}$ & $11 \mathrm{~h}$ \\
\hline $\mathrm{R}$ & 2,6-di & $\mathrm{Cl}$ & $2-\mathrm{CI}$ & $4-\mathrm{N}, \mathrm{N}-$ di Me & $4-\mathrm{OH}$
\end{tabular} (iii)<smiles>O=C(NNC(=O)C(F)(F)F)c1ccc(NC(=O)c2cccnc2)cc1</smiles>

(10)

Scheme 2: General procedure for synthesis of target compounds 10 and 11a-h. Reagents and conditions: (i) ethyl 4-aminobenzoate, treithylamine (TEA), acetonitrile, stirring, rt; (ii) hydrazine hydrate, EtOH, reflux, $12 \mathrm{~h}$; (iii) triflouroacetic anhydride, DCM, stirring, rt; (iv) app. aldehyde, EtOH, g. acetic acid, reflux, $2 \mathrm{~h}$.

$5.28 \mu \mathrm{M}$ (HCT-116). Results revealed that derivatives including a substituted phenyl ring were more potent than those including an unsubstituted one. Derivatives with meta- or para-methoxy groups $7 \mathrm{a}$ and $7 \mathrm{~b}$, particularly, exhibited the highest cytotoxic activity throughout the series $\left(\mathrm{IC}_{50}=1.37,1.05\right.$, and $1.46 \mu \mathrm{M}$ for $7 \mathrm{a}$ and $1.25,2.12$, and $2.54 \mu \mathrm{M}$ for $7 \mathrm{~b}$ ) that assessed the importance of the terminal hydrophobic tail in increasing the cytotoxic activity. The potency of cytotoxic activity was, however, decreased by the introduction of electron donating groups, e.g., ortho-, meta-, or para-methyl $7 \mathrm{f}, 7 \mathrm{~h}$, and $7 \mathrm{j}$ as well as the $d i$-methyl substituted derivatives $7 \mathrm{k}$ ( $\mathrm{IC}_{50}$ ranging from 14.08 to $31.45 \mu \mathrm{M})$. Contrariwise, substitution of the phenyl ring with a strong electron withdrawing flouro group 71 dramatically potentiated the cytotoxic activity $\left(\mathrm{IC}_{50}=3.50,2.64\right.$, and $2.75 \mu \mathrm{M})$. On the other hand, incorporation of a cyclohexyl 5 moiety increased the activity $\left(\mathrm{IC}_{50}=4.66,3.29\right.$, and $1.60 \mu \mathrm{M})$, whereas the bulky benzyl group of compound 6 lowered the cytotoxic activity $\left(\mathrm{IC}_{50}=18.32,15.45\right.$, and $16.40 \mu \mathrm{M})$.

Investigation of the cytotoxicity results of the hydrazone containing series $11 \mathrm{a}-\mathrm{h}$ revealed that the compound with the para-methoxy phenyl moiety $11 \mathrm{~d}$ was, interestingly, the most active among this series with $\mathrm{IC}_{50}=4.15,2.23$, and $1.94 \mu \mathrm{M}$. Members with para-N,N-di-methyl $11 \mathrm{~g}$, parachloro 11f, or para-nitro 11c substituents on the phenyl ring were reported to possess high cytotoxic effects with $\mathrm{IC}_{50}$ ranging from 3.47 to $7.31 \mu \mathrm{M}$. Inversely, the activity was strongly decreased to $20.17,31.12$, and $34.9 \mu \mathrm{M}$ in the case of the para-hydroxy substituted compound $11 \mathrm{~h}$.
The in vitro antiproliferative effect of the trifluoroacetyl derivative 10 was better than that of sorafenib considering the MCF-7 and HepG-2 cell lines with $\mathrm{IC}_{50}$ values of 3.55 $3.16 \mu \mathrm{M}$, respectively, while its activity was almost equal to sorafenib regarding the $\mathrm{HCT}-116$ cell line with an $\mathrm{IC}_{50}$ value of $5.49 \mu \mathrm{M}$.

Concerning the oxadiazole linker containing series $18 \mathrm{a}$ $c$, it was noticed that the compound bearing an unsubstituted phenyl ring as a hydrophobic tail $18 \mathrm{~b}$ was the most effective against the three tested cancer cell lines with $\mathrm{IC}_{50}$ values of $2.67,6.11$, and $4.19 \mu \mathrm{M}$. The cytotoxic activity was lowered with the para-chloro substituted phenyl moiety $18 \mathrm{a}\left(\mathrm{IC}_{50}=5.81,8.29\right.$, and $\left.5.13 \mu \mathrm{M}\right)$, while, it was the least in the member with a benzyl moiety $18 \mathrm{c}(\mathrm{IC} 50=19.37,8.59$, and $21.72 \mu \mathrm{M})$.

The cytotoxicity values of the synthesized compounds against the WI-38 cell line (normal human lung fibroblasts) were also evaluated in vitro. The results revealed that the tested compounds have low toxicity against WI-38 with I $\mathrm{C}_{50}$ values ranging from 50.28 to $157.19 \mu \mathrm{M}$.

2.2.2. In Vitro VEGFR-2 Enzyme Assay Inhibition. In order to determine the potency of the design compounds as VEGFR-2 inhibitors, we decided to investigate the inhibitory effect of the most active cytotoxic members against VEGFR2 with sorafenib as positive control [48]. Results are illustrated in Table 2. Most of the tested compounds showed moderate to potent inhibition of VEGFR-2 in comparison to the reference drug, sorafenib $\left(\mathrm{IC}_{50}=2.36 \mu \mathrm{M}\right)$. The $\mathrm{IC}_{50}$ values of the tested compounds ranged from 2.17 to 
<smiles>O=C(O)c1cccnc1</smiles>

(1) (ii)<smiles>CCCCCCC</smiles>

(12)<smiles>COC(=O)c1cccnc1</smiles>

12) (iii)<smiles>NNC(=O)c1cccnc1</smiles>

(13)

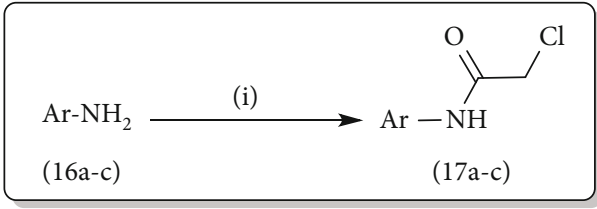<smiles>Sc1nnc(-c2cccnc2)o1</smiles>

(v)<smiles>CC(C)(C)NC(=O)CSc1nnc(-c2cccnc2)o1</smiles>

(vi)<smiles>[SiH3]c1nnc(-c2cccnc2)o1</smiles>

(15)<smiles>CC(C)(C)Cc1ccc(Cl)cc1</smiles>

Scheme 3: General procedure for synthesis of target compounds 18a-c. Reagents and conditions: (i) chloroacetylchloride, DMF, stirring, $12 \mathrm{~h}$; (ii) $\mathrm{MeOH}$, sulfuric acid, reflux, $4 \mathrm{~h}$; (iii) hydrazine hydrate, $\mathrm{EtOH}$, reflux, 8 h; (iv) (1) carbon disulfide, $\mathrm{KOH}, \mathrm{EtOh}, \mathrm{reflux}, 12 \mathrm{~h}$, (2) $\mathrm{HCl}$; (v) $\mathrm{KOH}$, absoluteEtOH, reflux, $0.5 \mathrm{~h}$; (vi) Comp 17a-c, DMF, Kl, heating, $4 \mathrm{~h}$.

$8.09 \mu \mathrm{M}$. In light of the VEGFR-2 inhibitory results, it was obvious that compound 7a significantly inhibited VEGFR2 tyrosine kinase with an $\mathrm{IC}_{50}$ value of $2.17 \mu \mathrm{M}$, a value which was lower than that of sorafenib, indicating the ability of the designed compound to block the VEGFR-2 signaling pathway with subsequent inhibition of angiogenesis. The cyclohexyl-containing compound 5 exhibited an inhibitory effect $\left(\mathrm{IC}_{50}=2.46 \mu \mathrm{M}\right)$ that was almost like sorafenib. Members $11 \mathrm{~d}$ and $7 \mathrm{~b}$, with a para-methoxy substituted phenyl moiety, possessed potent VEGFR-2 inhibitory activity with $\mathrm{IC}_{50}$ values of 2.74 and $3.45 \mu \mathrm{M}$, respectively. The halogenated derivatives $7 \mathrm{l}, 11 \mathrm{f}$, and $18 \mathrm{a}$ showed strong inhibitory effects with $\mathrm{IC}_{50}$ values of $3.84,4.17$, and $5.23 \mu \mathrm{M}$, respectively. The rest of the tested compounds exhibited moderate inhibitory activities with $\mathrm{IC}_{50}$ values ranging from 6.12 to $8.09 \mu \mathrm{M}$.

\subsubsection{Apoptotic Marker Analysis}

(1) Effects on the Levels of Active Caspase-3. A significant mechanism by which anticancer agents can affect cancer cells is apoptosis. Apoptosis is a process of automated cell death. The apoptosis mechanism is typically mediated by a group of proteases called caspases. Caspase- 3 is activated in every mammalian cell type provoking the cell to die, considered one of the apoptosis marks. Therefore, the level of caspase- 3 was analyzed following exposure of the HepG-2 cell to the most active cytotoxic candidates. The tested compounds caused a potent increase in caspase- 3 level to a concentration ranging from 267.64 to $397.61 \mathrm{Pg} / \mathrm{ml}$ (Table 3). Compounds $7 \mathrm{a}, 7 \mathrm{~b}$, and $11 \mathrm{~d}$ exhibited more than 7 -fold increases in the caspase- 3 level when compared with the control indicating their ability to activate caspase- 3 enzymes and dramatically reinforce apoptosis of cancer cells (Figure 3).

(2) Effects on Bcl-2 Family Proteins. The Bcl-2 family proteins are vital regulators of apoptosis cell death. Members of this family include the proapoptotic factor Bax which promotes cell death and the prosurvival (antiapoptotic) Bcl-2 which suppresses cell death. Bax and Bcl-2 cellular levels were analyzed for the most potent cytotoxic compounds in HepG-2 cells. Results are expressed in Table 3. The tested compounds caused an increase in the proapoptotic factor Bax by 5.25- to 12.11-fold (Figure 4), while a decrease in the antiapoptotic protein $\mathrm{Bcl}-2$ concentration was observed 
TABLE 1: $\mathrm{IC}_{50}$ values of the MTT assayed compounds against the tested cell lines.

\begin{tabular}{|c|c|c|c|c|c|}
\hline Comp. & Structure & MCF-7 & HepG-2 & HCT-116 & WI-38 \\
\hline 5 & & 4.66 & 3.29 & 1.60 & 61.39 \\
\hline 6 & & 18.32 & 15.45 & 16.40 & 117.36 \\
\hline $7 \mathrm{a}$ & & 1.37 & 1.05 & 1.46 & 60.8 \\
\hline $7 \mathrm{~b}$ & & 1.25 & 2.12 & 2.54 & 82.17 \\
\hline $7 \mathrm{c}$ & & 11.79 & 19.41 & 15.34 & 136.51 \\
\hline $7 \mathrm{~d}$ & & 23.11 & 29.14 & 31.47 & 143.82 \\
\hline $7 \mathrm{e}$ & & 13.38 & 22.41 & 17.80 & 142.63 \\
\hline
\end{tabular}


TABle 1: Continued.

\begin{tabular}{|c|c|c|c|c|c|}
\hline Comp. & Structure & MCF-7 & HepG-2 & НCТ-116 & WI-38 \\
\hline $7 \mathrm{f}$ & & 20.46 & 31.45 & 18.30 & 157.19 \\
\hline $7 \mathrm{~g}$ & & 42.10 & 26.55 & 31.70 & 131.54 \\
\hline $7 \mathrm{~h}$ & & 19.20 & 14.90 & 22.70 & 95.14 \\
\hline $7 \mathrm{i}$ & & 16.15 & 15.22 & 18.40 & 103.26 \\
\hline $7 \mathrm{j}$ & & 16.80 & 14.08 & 15.10 & 84.92 \\
\hline $7 \mathrm{k}$ & & 17.14 & 20.05 & 18.70 & 75.31 \\
\hline 71 & & 3.50 & 2.64 & 2.75 & 68.21 \\
\hline
\end{tabular}


TABLE 1: Continued.

Comp.

10<smiles>O=C(NNC(=O)C(F)(F)F)c1ccc(NC(=O)c2cccnc2)cc1</smiles>

MCF-7

$11 \mathrm{a}$<smiles>O=C(N/N=C/c1ccc(F)cc1)c1ccc(NC(=O)c2cccnc2)cc1</smiles>

$11 \mathrm{~b}$<smiles>O=C(N/N=C/c1ccccc1)c1ccc(NC(=O)c2cccnc2)cc1</smiles>

$11 \mathrm{c}$<smiles>O=C(N/N=C/c1ccc([N+](=O)[O-])cc1)c1ccc(NC(=O)c2cccnc2)cc1</smiles>

11d<smiles>COc1ccc(/C=N/NC(=O)c2ccc(NC(=O)c3cccnc3)cc2)cc1</smiles>

$11 \mathrm{e}$<smiles>O=C(N/N=C/c1c(Cl)cccc1Cl)c1ccc(NC(=O)c2cccnc2)cc1</smiles>

11f<smiles>O=C(N/N=C/c1ccccc1Cl)c1ccc(NC(=O)c2cccnc2)cc1</smiles>

3.55

12.31

HepG-2 HCT-116

WI-38

15.54

17.62

13.44

72.28

6.29

7.31

5.72

52.31

4.15

2.23

1.94

50.28

18.22

23.91

14.52

80.06

6.15

7.05

3.47

62.37 
TABLE 1: Continued.

\begin{tabular}{|c|c|c|c|c|c|}
\hline Comp. & Structure & MCF-7 & HepG-2 & HCT-116 & WI-38 \\
\hline $11 \mathrm{~g}$ & $\mathrm{H}$ & 5.73 & 6.42 & 4.80 & 70.14 \\
\hline $11 \mathrm{~h}$ & $\mathrm{H}$ & 20.17 & 31.12 & 34.9 & 103.22 \\
\hline $18 \mathrm{a}$ & & 5.81 & 8.29 & 5.13 & 123.42 \\
\hline $18 \mathrm{~b}$ & & 2.67 & 6.11 & 4.19 & 64.35 \\
\hline $18 \mathrm{c}$ & & 19.37 & 8.59 & 21.72 & 92.11 \\
\hline Sorafenib & - & 4.32 & 3.76 & 5.28 & - \\
\hline
\end{tabular}

TABLE 2: IC $_{50}$ values of the tested compounds against VEGFR-2.

\begin{tabular}{ll}
\hline Comp. & $\mathrm{IC}_{50}$ \\
\hline 5 & 2.46 \\
$7 \mathrm{a}$ & 2.17 \\
$7 \mathrm{~b}$ & 3.45 \\
$7 \mathrm{l}$ & 3.84 \\
10 & 7.68 \\
$11 \mathrm{c}$ & 8.09 \\
$11 \mathrm{~d}$ & 2.74 \\
$11 \mathrm{f}$ & 4.17 \\
$11 \mathrm{~g}$ & 6.12 \\
$18 \mathrm{a}$ & 5.23 \\
$18 \mathrm{~b}$ & 6.57 \\
Sorafenib & 2.36 \\
\hline
\end{tabular}

by 0.23 - to 0.52 -fold in comparison to the control (Figure 5) indicating that the tested members promote apoptosis via both the intrinsic and extrinsic pathways.

(3) Cell Cycle Analysis. For further investigation of the apoptotic capacity of compound $7 \mathrm{a}$, flow cytometric analysis was carried out on the HepG-2 cancer cell line treated with the tested compound at its $\mathrm{IC}_{50}$ concentrations using untreated HepG-2 cancer cells as a negative control. An elevation of apoptotic cells at the pre-G1 phase was observed (10.5\%) in comparison to the control HepG-2 cells $(2.0 \%)$. Accumulation of cells at the G2-M phase for 7 a was estimated to be $46.74 \%$ versus $23.11 \%$ accumulation for control HepG-2 cells. On the contrary, the percentage at the S phase of treated cells was reduced $(22.11 \%)$ compared to untreated cells (28.57\%) (Figure 6).

(4) Effect of Compound 7a on VEGFR-2 Protein Expression. Western blotting found that $10 \mathrm{~h}$ exposures to $7 \mathrm{a}$ in HepG- 
TABLE 3: Caspase 3 concentrations, BAX and Bcl-2 expression levels, and TNF- $\alpha$ percent inhibition in HepG-2 cells treated with the tested compounds.

\begin{tabular}{|c|c|c|c|c|c|c|c|}
\hline \multirow{2}{*}{ Comp. } & \multicolumn{2}{|c|}{ Caspase 3} & \multicolumn{2}{|c|}{ BAX } & \multicolumn{2}{|c|}{ Bcl-2 } & \multirow{2}{*}{$\begin{array}{c}\text { TNF- } \alpha \\
\% \text { inhibition }\end{array}$} \\
\hline & Conc. (Pg/ml) & Fold & Conc. $(\mathrm{Pg} / \mathrm{ml})$ & Fold & Conc. (Pg/ml) & Fold & \\
\hline $11 \mathrm{c}$ & 271.41 & 5.28 & 133.2 & 6.17 & 2.81 & 0.52 & $31 \%$ \\
\hline $11 d$ & 391.23 & 7.61 & 237.9 & 11.02 & 1.72 & 0.32 & $81 \%$ \\
\hline $11 \mathrm{f}$ & 292.11 & 5.68 & 142.5 & 6.60 & 2.25 & 0.42 & $60 \%$ \\
\hline $11 \mathrm{~g}$ & 324.36 & 6.31 & 160.2 & 7.42 & 2.55 & 0.48 & $47 \%$ \\
\hline 10 & 334.57 & 6.51 & 231.6 & 10.73 & 2.72 & 0.51 & $40 \%$ \\
\hline $18 \mathrm{~b}$ & 310.75 & 6.04 & 154.4 & 7.15 & 2.51 & 0.47 & $54 \%$ \\
\hline $18 \mathrm{a}$ & 267.64 & 5.20 & 113.5 & 5.26 & 2.63 & 0.49 & $45 \%$ \\
\hline $7 \mathrm{a}$ & 401.15 & 7.80 & 261.4 & 12.11 & 1.25 & 0.23 & $87 \%$ \\
\hline $7 b$ & 397.61 & 7.73 & 257.5 & 11.93 & 1.92 & 0.36 & $72 \%$ \\
\hline 5 & 345.5 & 6.72 & 232.7 & 10.78 & 1.35 & 0.25 & $85 \%$ \\
\hline 71 & 340.42 & 6.62 & 226.9 & 10.51 & 2.11 & 0.39 & $74 \%$ \\
\hline Control & 51.38 & 1.00 & 21.57 & 1.00 & 5.31 & 1.00 & $86 \%$ \\
\hline
\end{tabular}

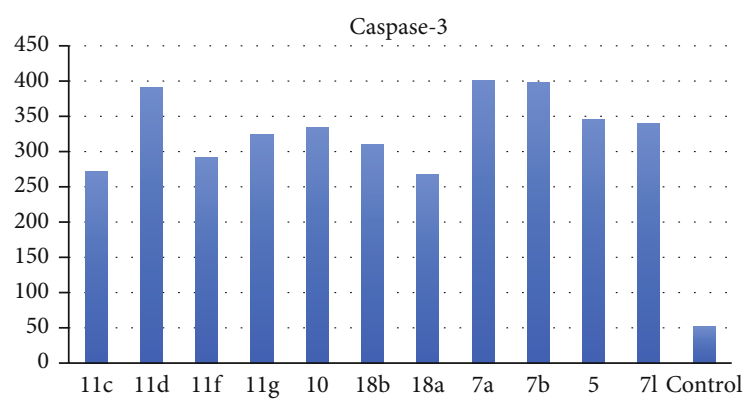

Figure 3: Levels of caspase-3 in the cell supernatant after exposure to the synthesized compounds on HepG-2 cells.

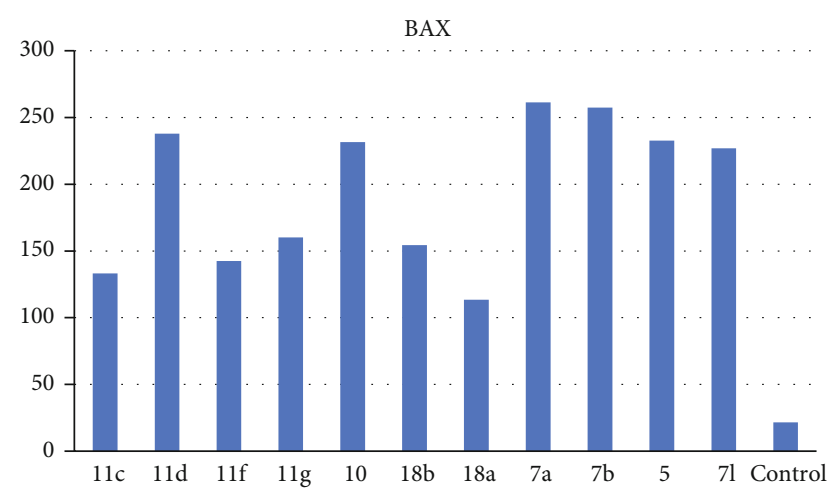

FIGURE 4: BAX levels caused by the tested compounds on HepG-2.

2 cells downregulated the expression of VEGFR-2 protein in comparison to the blank (Figure 7).

(5) Apoptotic Cell Subpopulation Determination. To support the fact that derivative $7 \mathrm{a}$ induces apoptosis in the HepG-2 cancer cell line, annexin V-FITC and PI double-staining assay protocol was used. Figure 8 displays the percentage of early and late apoptotic stages following the treatment of HepG-2 cells with the $\mathrm{IC}_{50}$ dose of compound $7 \mathrm{a}$ $(2.17 \mu \mathrm{M})$ for $24 \mathrm{~h}$. The percentage of early and late apopto-

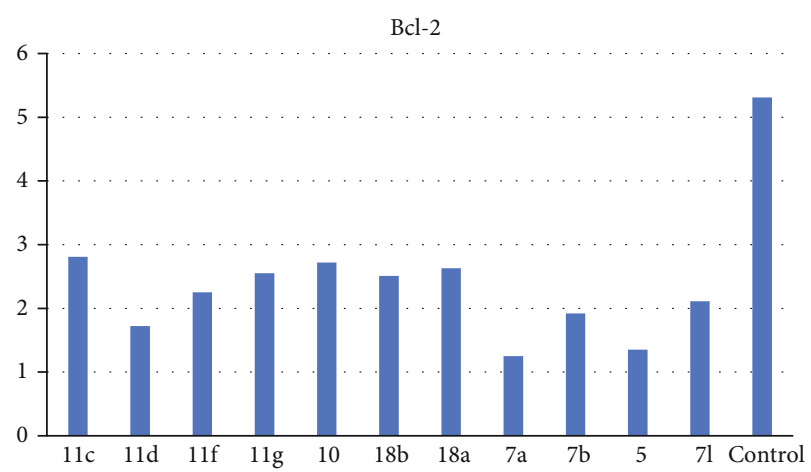

FIgUre 5: Bcl-2 levels caused by the tested compounds on HepG-2.

tic populations increased from $0.91 \%$ and $0.58 \%$, respectively, in control untreated cells to $7.41 \%$ and $6.80 \%$ in $7 \mathrm{a}-$ treated cells. This is evidence that the antiproliferative activities are associated with a proapoptotic effect of the tested compound.

\subsubsection{In Vitro Immunomodulatory Assay}

(1) Estimation of Human Tumor Necrosis Factor Alpha (TNF- $\alpha$ ) in HepG-2 Supernatant. The effect of the most active cytotoxic compounds on TNF- $\alpha$ was also examined aiming to study their immunomodulatory effect on HepG2 cells. Celecoxib, a potent inhibitor of TNF- $\alpha$-induced cytokine expressions, was used as a positive control [49]. The data represented in Table 3 revealed that production of TNF- $\alpha$ was significantly decreased in HepG- 2 cells exposed to celecoxib and the synthesized compounds compared to the untreated HepG-2 cells. Among the tested compounds, compound 7 a caused a remarkably significant reduction in TNF- $\alpha$ levels (87\%) in comparison to celecoxib (86\%). The rest of the tested compounds exhibited moderate to potent TNF- $\alpha$ level reduction in relation to the reference drug.

2.2.5. Effect on Vascular Smooth Muscle Cell Proliferation in a Concentration-Dependent Manner. In order to examine its 

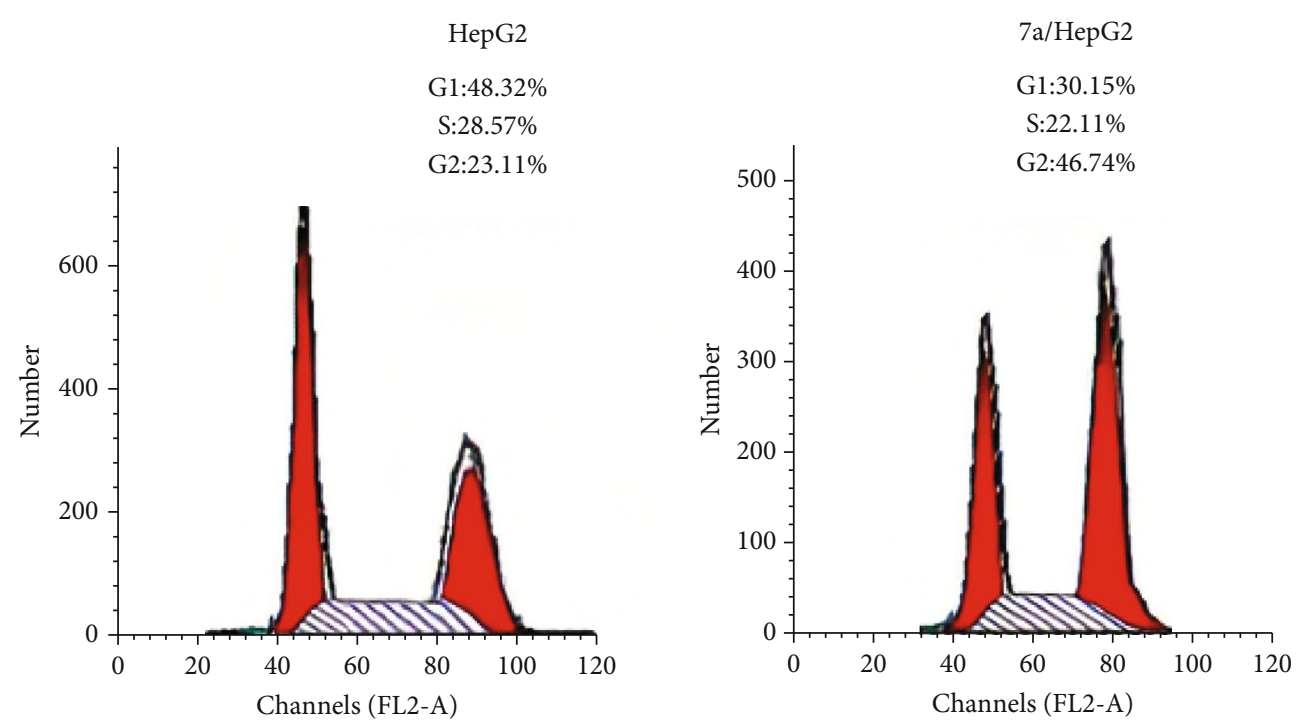

Figure 6: Cell cycle analysis of HepG-2 cells treated with compound 7a.

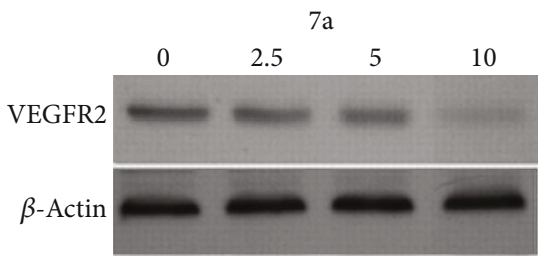

FiguRE 7: Effect of 7a on VEGFR-2 protein expression.
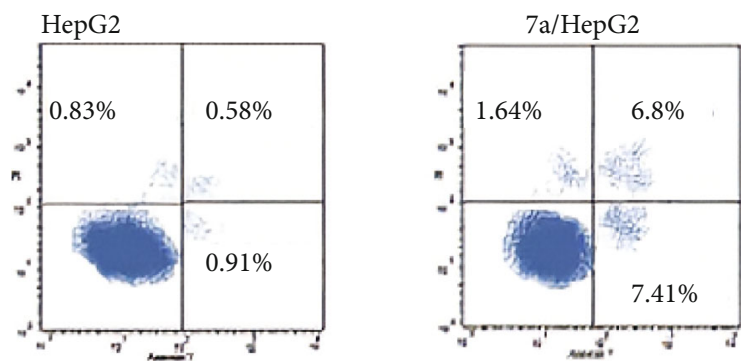

Figure 8: Effect of compound 7a on the percentage of annexin VFITC-positive staining in HepG-2 cells.

effect on the proliferation of vascular smooth muscle cells (VSMCs), VSMCs were treated with increasing concentrations of compound $7 \mathrm{a}(2.5,5$, and $10 \mu \mathrm{M})$ for $48 \mathrm{~h}$. The cellular proliferation results are illustrated in Figure 9. Results revealed that compound $7 \mathrm{a}$ had a significant antiproliferative effect at all concentrations tested, although the effect was more profound with concentrations of $5 \mu \mathrm{M}$ or higher.

2.3. Docking Study. The newly synthesized compounds underwent molecular docking studies in order to shed light on their interaction with the ATP pocket of VEGFR-2 using Molecular Operating Environment (MOE, 2014) software. The X-ray crystallographic structure of VEGFR-2 (PDB ID: 4ASD) with its cocrystalized type II PK inhibitor, sorafenib,
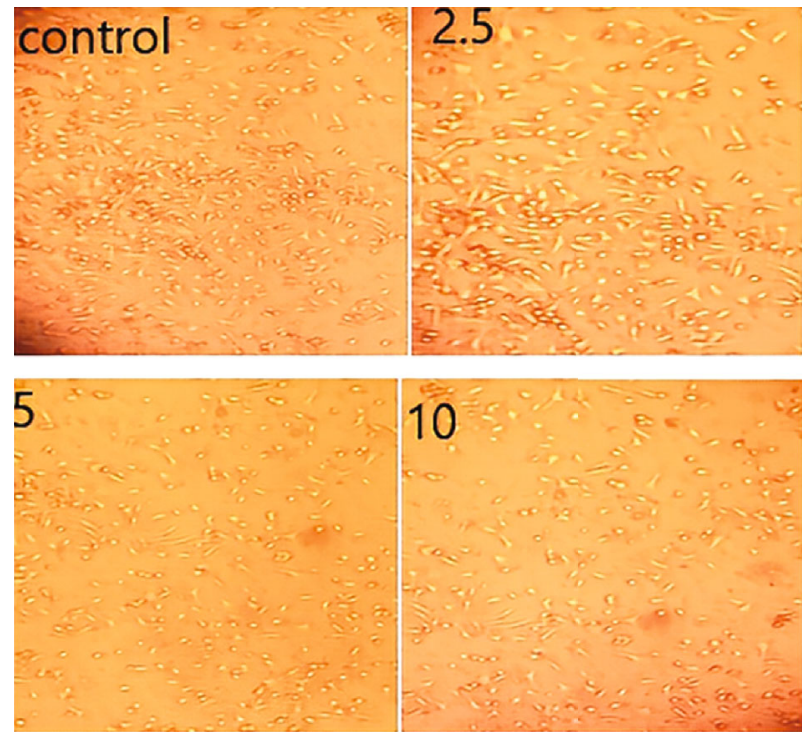

Figure 9: Effect of compound 7a on VSMC proliferation.

was downloaded from the Protein Data Bank (PDB). Redocking of the cocrystalized ligand, sorafenib, was initially performed aiming at validating the used docking protocol. The simulation of the redocked ligand successfully regenerated the same binding mode of the cocrystalized one inside the VEGFR-2 active site with an RMSD of $0.65 \AA$. The redocked poses reproduced all crucial interactions carried out by the cocrystallized ligand with the VEGFR-2 active site including Cys919, Glu885, and Asp1046 residues. Results of the validation step signaled that the used docking protocol is suitable for a molecular docking study of the designed compounds in the VEGFR-2 active pocket (Figure 10).

A general examination of docking results revealed that the designed compounds exhibited a binding pattern comparable to that of the native ligand with predicted binding energy scores ranging from -27.18 to $-56.91 \mathrm{kcal} / \mathrm{mol}$. 


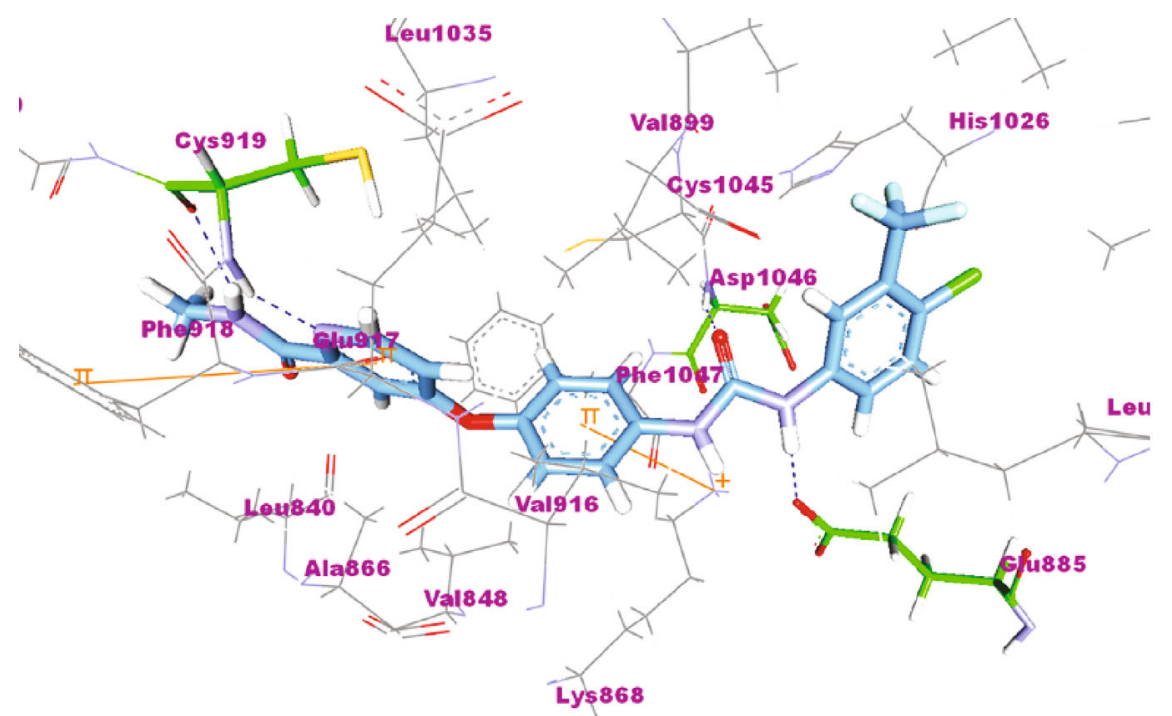

(a)

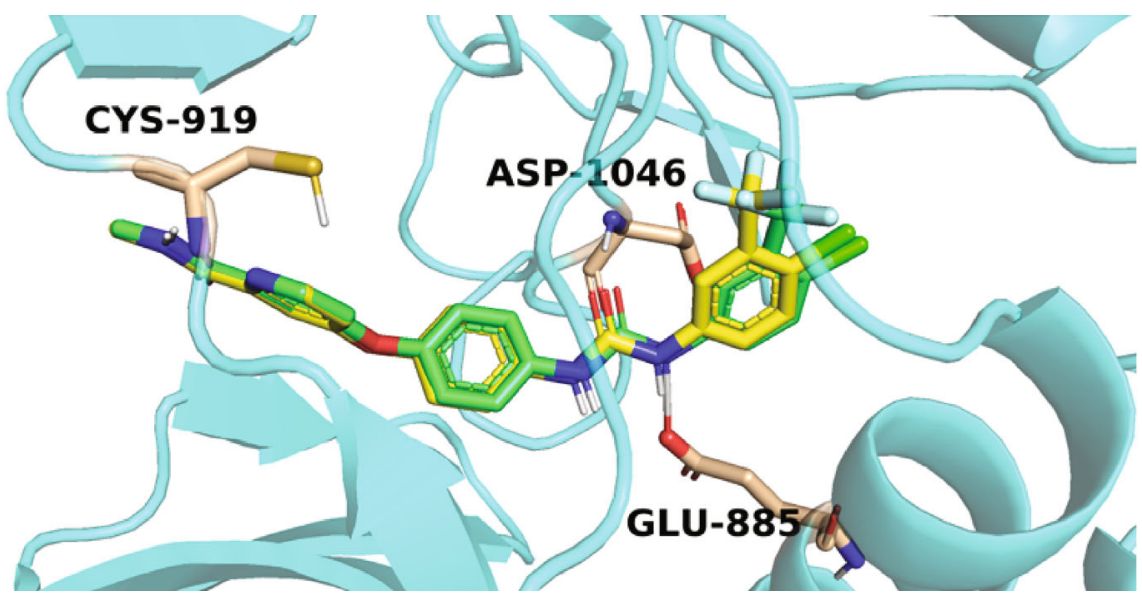

(b)

FIGURE 10: (a) Docking pose of sorafenib. (b) Superimposition of the cocrystallized pose (green) and the docking pose (yellow) of the same ligand.

The synthesized compounds occupied the same orientation of sorafenib. They interacted with the key amino acids in the active site of VEGFR-2 in the same manner achieved by sorafenib. The compounds nicotinamide or pyridin-3yl-oxadiazol moieties were directed toward the hinge region of the active side forming a hydrogen bond between their pyridinyl nitrogen and Cys919 residue. On the other side, the carbamoyl phenyl, hydrazine-carbonyl phenyl, and thioacetamide scaffolds of the designed compounds were accommodated in the pocket central area, i.e., the gate area, interacting via a hydrogen bond with the carboxylate side chain of Glu885 and another one with the $\mathrm{NH}$ moiety of Asp1046 of the conserved DFG motif in VEGFR-2. The orientation of the later moieties fitted the compounds' hydrophobic substituents in the hydrophobic allosteric pocket in the active site allowing these hydrophobic substituents to interact with hydrophobic side chains of Ile888, Leu889, Ile892, Val898, Val899, Leu1019, and Ile1044 amino acids lining the back pocket of VEGFR-2 (Figure 11).

\section{Conclusion}

Three series of pyridine-containing compounds have been synthesized and tested for their in vitro cytotoxic activity against HepG-2, MCF-7, and HCT-116 cancer cell lines by an MTT assay. In vitro $\mathrm{IC}_{50}$ determination of the best eleven derivatives were evaluated against the VEGFR-2 enzyme. Compound $7 \mathrm{a}$ was found to be the most potent especially against HepG-2 cells. A caspase-3 activation assay was performed for the most active members in HepG-2 cells. Compound 7a significantly increased the caspase- 3 level by 7.80 fold $(401.15 \mathrm{Pg} / \mathrm{ml})$ compared to the control $(51.38 \mathrm{Pg} / \mathrm{ml})$. In addition, Bax and Bcl-2 concentration levels were estimated. Compound $7 \mathrm{a}$ results showed a titer increase of the proapoptotic protein $\mathrm{Bax}(261.4 \mathrm{Pg} / \mathrm{ml})$ and a decrease of the antiapoptotic protein $\mathrm{Bcl}-2(1.25 \mathrm{Pg} / \mathrm{ml})$ compared to the untreated HepG-2 cells. Furthermore, compound $7 \mathrm{a}$ arrested the cell cycle in the G2/M phase with induction of apoptosis in HepG-2 cells. The immunomodulatory effect 


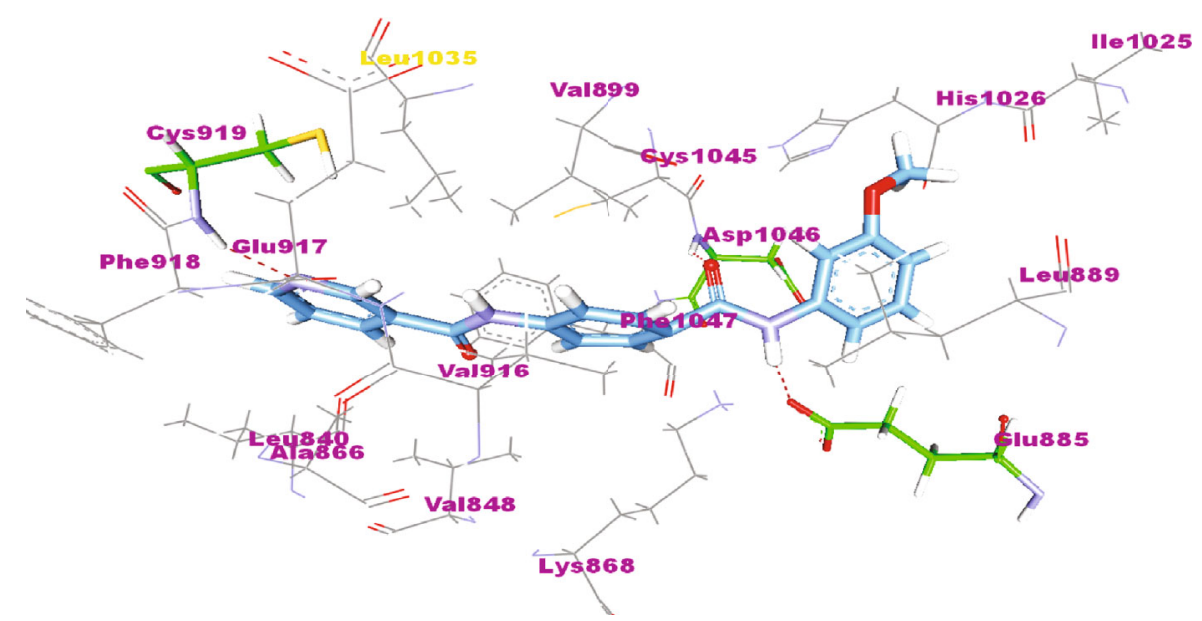

(a)

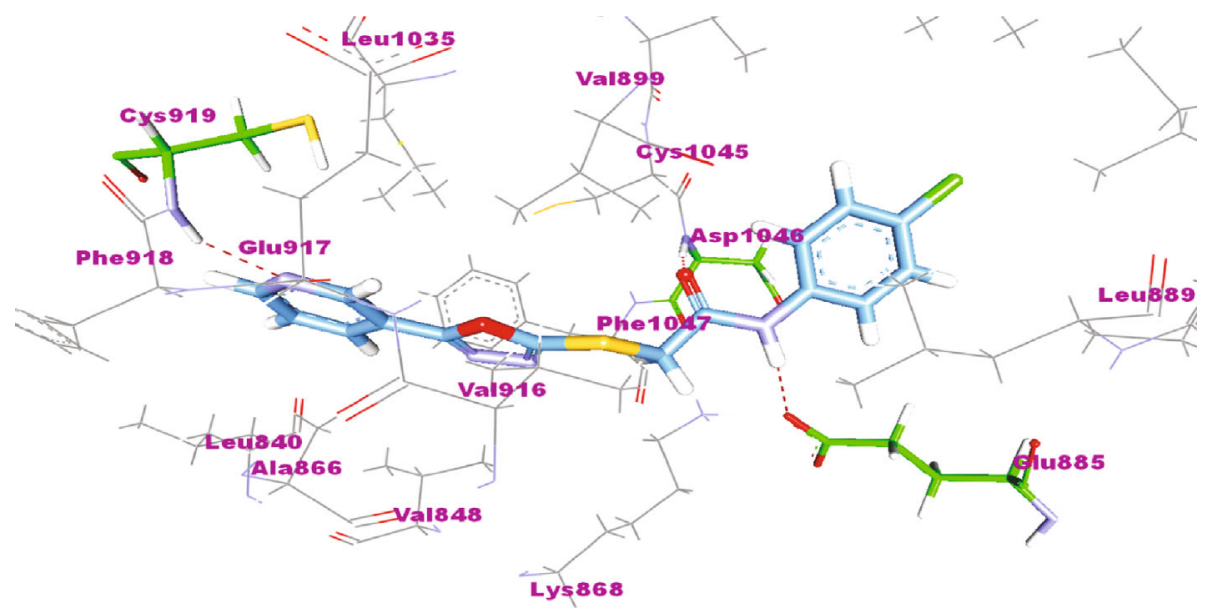

(b)

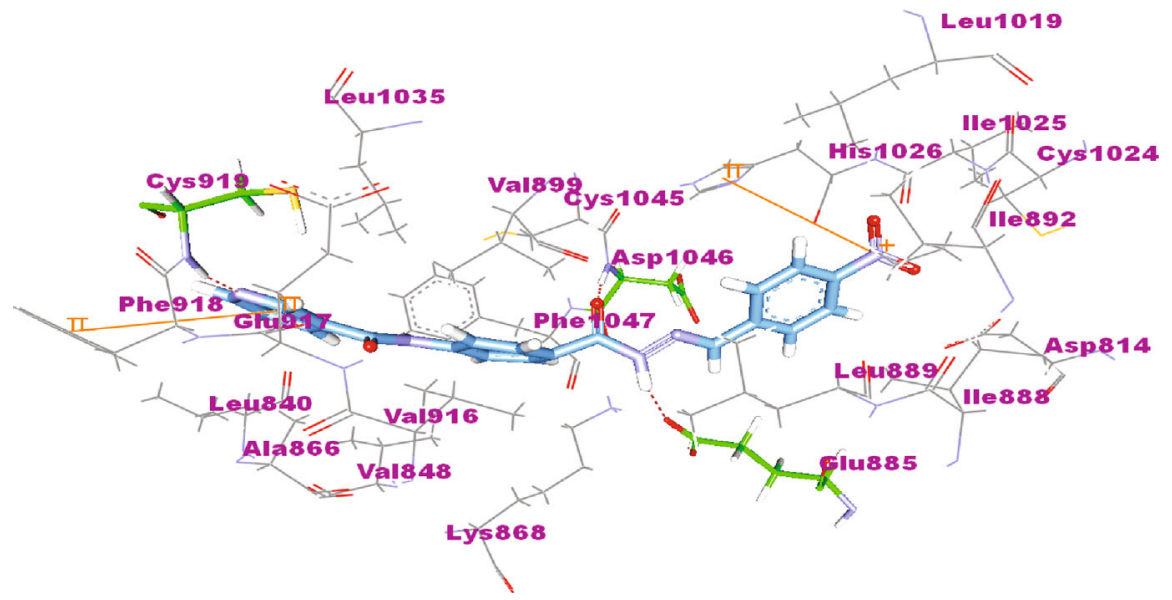

(c)

FIGURE 11: The proposed binding pose for the interaction of 7a (a), 18a (b), and 18c (c) in the active site of VEGFR-2 (PDB ID: 4ASD).

of the most active members was also evaluated with a significant reduction in TNF- $\alpha$ by $87 \%$ for compound $7 \mathrm{a}$. Compound $7 \mathrm{a}$ also caused a potent inhibitory effect on smooth muscle proliferation. The biological results were supported by docking studies via prediction of the possible binding pattern of the target compounds with VEGFR-2 active sites.

\section{Experimental Section}

4.1. Chemistry. Determination of melting points was carried out using a Gallen lamp melting point apparatus and is uncorrected. Reaction progress was monitored by TLC (Merck, Germany), and the spots were detected by exposure 
to UV lamp at $\lambda 254 \mathrm{~nm}$. IR spectra were recorded on a Pye Unicam SP 1000 IR spectrophotometer using $\mathrm{KBr}$ discs and expressed in wave number $\left(\mathrm{cm}^{-1}\right),{ }^{1} \mathrm{H}$ and ${ }^{13} \mathrm{C}$ NMR spectra were recorded with a Bruker Advance 400 spectrophotometer operating at $400 \mathrm{MHz}$ and $100 \mathrm{MHz}$, respectively, and the chemical shifts were given in $\delta$ as parts per million (ppm) downfield from tetramethylsilane (TMS) as internal standard. The mass spectra were recorded on a Varian MAT 311-A $(70 \mathrm{eV})$.

The following compounds were prepared according to the reported procedures: nicotinoyl chloride 2, 4-(nicotinamido)benzoic acid 3, 4-(nicotinamido)benzoyl chloride 4, ethyl 4-(nicotinamido)benzoate $8, \mathrm{~N}$-(4-(hydrazine-carbonyl)phenyl)nicotinamide 9, methyl nicotinate 12 , nicotinohydrazide 13, 5-(pyridin-3-yl)-1,3,4-oxadiazole-2-thiol 14, potassium 5-(pyridin-3-yl)-1,3,4-oxa-diazole-2-thiolate 15, and $\mathrm{N}$-aryl-2-chloroacetamides $17 \mathrm{a}$-c.

4.1.1. General Procedure for Synthesis of Compounds 5, 6, and $7 a-l$. To a solution of 4-(nicotinamido)benzoyl chloride $4(0.26 \mathrm{~g}, 0.001 \mathrm{~mol})$ in acetonitrile $(25 \mathrm{ml})$, the appropriate alkyl amine, namely, cyclohexylamine or benzylamine, or the appropriate aniline derivative, namely, 3-methoxyaniline, 4methoxyaniline, 2-methoxyaniline, aniline, 4-chloroaniline, $o$-toluidine, 2,4-dichloroaniline, $m$-toluidine, 2-nitroaniline, p-toluidine, 2,4-dimethylaniline, or 4-fluoroaniline was added. TEA was added to the mixture in a catalytic proportion. The reaction mixture was then refluxed for $2 \mathrm{~h}$. The reaction mixture was poured onto ice water, and the residue was filtered off and crystallized from ethanol.

(1) N-(4-(Cyclohexylcarbamoyl)phenyl)nicotinamide (5). Yield: $87 \%$; melting point: $239-242^{\circ} \mathrm{C}$; HPLC purity 96.93\%; IR $v_{\max } / \mathrm{cm}^{-1}: 3321(\mathrm{NH}), 1651,1630(\mathrm{C}=\mathrm{O}) ;{ }^{1} \mathrm{H}$ NMR (DMSO-d6, $400 \mathrm{MHz}) \delta$ ppm: $1.13(\mathrm{~m}, 1 \mathrm{H}), 1.26-$ $1.37(\mathrm{~m}, 4 \mathrm{H}), 1.61(\mathrm{~m}, 1 \mathrm{H}), 1.75(\mathrm{~m}, 2 \mathrm{H}), 2.84(\mathrm{~m}, 2 \mathrm{H})$, $3.77(\mathrm{~m}, 1 \mathrm{H}), 7.59(\mathrm{dd}, J=8.0,8.0 \mathrm{~Hz}, 1 \mathrm{H}), 7.85(\mathrm{~m}, 4 \mathrm{H})$, $8.15(\mathrm{~d}, J=8.0 \mathrm{~Hz}, 1 \mathrm{H}), 8.31(\mathrm{t}, J=8.0 \mathrm{~Hz}, 1 \mathrm{H}), 8.78(\mathrm{~d}, J$ $=6.8 \mathrm{~Hz}, 1 \mathrm{H}), 9.13(\mathrm{~s}, 1 \mathrm{H}), 10.67(\mathrm{~s}, 1 \mathrm{H}) ;{ }^{13} \mathrm{C} \mathrm{NMR}$ (DMSO-d6) $\delta$ (ppm): 25.47 (2C), 25.77, 32.97 (2C), 48.76, 119.83 (2C), 124.00, 128.51 (2C), 130.48, 130.87, 136.04, $141.74,149.23,152.74,164.78,165.20$.

(2) N-(4-(Benzylcarbamoyl)phenyl)nicotinamide (6). Yield: 74\%; melting point: $229-232^{\circ} \mathrm{C}$; HPLC purity $98.17 \%$; IR $v_{\max } / \mathrm{cm}^{-1}: 3313,3174(\mathrm{NH}), 1654,1632(\mathrm{C}=\mathrm{O}) ;{ }^{1} \mathrm{H}$ NMR (DMSO- $d 6,400 \mathrm{MHz}) \delta \mathrm{ppm}: 4.5(\mathrm{~s}, 2 \mathrm{H}), 7.26(\mathrm{~s}, 1 \mathrm{H})$, $7.34(\mathrm{~m}, 4 \mathrm{H}), 7.59(\mathrm{dd}, J=8.0,7.6 \mathrm{~Hz}, 1 \mathrm{H}), 7.89(\mathrm{~d}, J=8.4$ $\mathrm{Hz}, 2 \mathrm{H}), 7.94(\mathrm{~d}, J=8.4 \mathrm{~Hz}, 2 \mathrm{H}), 8.32(\mathrm{~d}, J=7.6 \mathrm{~Hz}, 1 \mathrm{H})$, 8.79 (s, 1H), $9.02(\mathrm{t}, J=6.4 \mathrm{~Hz}, 1 \mathrm{H}), 9.14(\mathrm{~s}, 1 \mathrm{H}), 10.68$ (s, $1 \mathrm{H}) ;{ }^{13} \mathrm{C}$ NMR (DMSO-d6) $\delta$ (ppm): 43.05, 119.97 (2C), $124.02,127.20,127.71$ (2C), 128.54 (2C), 128.76 (2C), $129.98,130.87,136.05,140.27,141.98,149.23,152.77$, $164.84,166.12$.

(3) $\mathrm{N}$-(4-((3-Methoxyphenyl)carbamoyl)phenyl)nicotinamide (7a). Yield: $84 \%$; melting point: $188-191^{\circ} \mathrm{C}$; HPLC purity 96.21\%; IR $v_{\max } / \mathrm{cm}^{-1}: 3348(\mathrm{NH}), 1665,1651(\mathrm{C}=\mathrm{O}) ;{ }^{1} \mathrm{H}$ NMR (DMSO-d6, $400 \mathrm{MHz}) \delta$ ppm: 3.77 (s, 3H), 6.68 (d,
$J=7.2 \mathrm{~Hz}, 1 \mathrm{H}), 7.24(\mathrm{t}, J=8.0 \mathrm{~Hz}, 1 \mathrm{H}), 7.40(\mathrm{~d}, J=8.0 \mathrm{~Hz}$, $1 \mathrm{H}), 7.51(\mathrm{~s}, 1 \mathrm{H}), 7.59(\mathrm{dd}, J=8.0,8.0 \mathrm{~Hz}, 1 \mathrm{H}), 7.95(\mathrm{~d}, J$ $=8.4 \mathrm{~Hz}, 2 \mathrm{H}), 8.01(\mathrm{~d}, J=8.4 \mathrm{~Hz}, 2 \mathrm{H}), 8.33(\mathrm{~d}, J=7.6 \mathrm{~Hz}$, $1 \mathrm{H}), 8.79(\mathrm{~s}, 1 \mathrm{H}), 9.16(\mathrm{~s}, 1 \mathrm{H}), 10.18(\mathrm{~s}, 1 \mathrm{H}), 10.74(\mathrm{~s}, 1 \mathrm{H})$; ${ }^{13} \mathrm{C}$ NMR (DMSO-d6) $\delta$ (ppm): 55.46, 106.46, 109.51, $113.01,119.97$ (2C), 124.02, 129.03 (2C), 130.39, 130.60, $130.84,136.08,140.94,142.35,149.26,152.80,159.89$, 164.91, 165.38 .

(4) N-(4-((4-Methoxyphenyl)carbamoyl)phenyl)nicotinamide (7b). Yield: $71 \%$; melting point: $249-251^{\circ} \mathrm{C}$; HPLC purity 98.65\%; IR $v_{\max } / \mathrm{cm}^{-1}: 3336(\mathrm{NH}), 1662,1640(\mathrm{C}=\mathrm{O}) ;{ }^{1} \mathrm{H}$ NMR (DMSO-d6, $400 \mathrm{MHz}) \delta$ ppm: $3.76(\mathrm{~s}, 3 \mathrm{H}), 6.93(\mathrm{~d}$, $J=8.4 \mathrm{~Hz}, 2 \mathrm{H}), 7.59(\mathrm{t}, J=6.0 \mathrm{~Hz}, 1 \mathrm{H}), 7.69(\mathrm{~d}, J=8.4 \mathrm{~Hz}$, $2 \mathrm{H}), 7.93(\mathrm{~d}, J=8.0 \mathrm{~Hz}, 2 \mathrm{H}), 8.00(\mathrm{~d}, J=8.0 \mathrm{~Hz}, 2 \mathrm{H}), 8.33$ (d, $J=7.2 \mathrm{~Hz}, 1 \mathrm{H}), 8.79$ (s, 1H), $9.15(\mathrm{~s}, 1 \mathrm{H}), 10.09$ (s, 1H), $10.72(\mathrm{~s}, 1 \mathrm{H})$; mass $(\mathrm{m} / \mathrm{z})$ : $347.06\left(\mathrm{M}^{+}, 32 \%\right), 217.06(100 \%)$.

(5) N-(4-((2-Methoxyphenyl)carbamoyl)phenyl)nicotinamide (7c). Yield: $76 \%$; melting point: $185-187^{\circ} \mathrm{C}$; HPLC purity 98.53\%; IR $v_{\max } / \mathrm{cm}^{-1}: 3433,3305(\mathrm{NH}), 1681,1685(\mathrm{C}=\mathrm{O})$; ${ }^{1} \mathrm{H}$ NMR (DMSO-d6, $\left.400 \mathrm{MHz}\right) \delta \mathrm{ppm:} 3.86(\mathrm{~s}, 3 \mathrm{H}), 6.99$ $(\mathrm{t}, J=8.4 \mathrm{~Hz}, 1 \mathrm{H}), 7.12(\mathrm{~d}, J=8.0 \mathrm{~Hz}, 1 \mathrm{H}), 7.19(\mathrm{~d}, J=7.6$ $\mathrm{Hz}, 1 \mathrm{H}), 7.61(\mathrm{~s}, 1 \mathrm{H}), 7.80(\mathrm{~d}, J=6.8 \mathrm{~Hz}, 1 \mathrm{H}), 7.95(\mathrm{~d}, J=$ $8.4 \mathrm{~Hz}, 2 \mathrm{H}), 8.00(\mathrm{~d}, J=8.4 \mathrm{~Hz}, 2 \mathrm{H}), 8.33(\mathrm{~d}, J=6.4 \mathrm{~Hz}$, $1 \mathrm{H}), 8.80(\mathrm{~s}, 1 \mathrm{H}), 9.15(\mathrm{~s}, 1 \mathrm{H}), 9.39(\mathrm{~s}, 1 \mathrm{H}), 10.73(\mathrm{~s}, 1 \mathrm{H})$; ${ }^{13} \mathrm{C}$ NMR (DMSO-d6) $\delta$ (ppm): 56.19, 111.82, 120.08 (2C), $120.69,124.06,124.69,126.09,127.35,128.84$ (2C), 129.99, $130.86,136.10,142.34,149.23,151.87,152.81,164.82,164.93$.

(6) N-(4-(Phenylcarbamoyl)phenyl)nicotinamide (7d). Yield: $82 \%$; melting point: $232-235^{\circ} \mathrm{C}$; HPLC purity $98.53 \%$; IR $v_{\max } / \mathrm{cm}^{-1}: 3344(\mathrm{NH}), 1665,1647 \quad(\mathrm{C}=\mathrm{O}) ;{ }^{1} \mathrm{H} \quad \mathrm{NMR}$ (DMSO-d6, $400 \mathrm{MHz}) \delta$ ppm: $7.09(\mathrm{t}, J=7.6 \mathrm{~Hz}, 1 \mathrm{H}), 7.36$ $(\mathrm{t}, J=8.0 \mathrm{~Hz}, 2 \mathrm{H}), 7.62(\mathrm{dd}, J=7.6,7.6 \mathrm{~Hz}, 1 \mathrm{H}), 7.79(\mathrm{~d}, J$ $=8.0 \mathrm{~Hz}, 2 \mathrm{H}), 7.95(\mathrm{~d}, J=8.8 \mathrm{~Hz}, 2 \mathrm{H}), 8.02(\mathrm{~d}, J=8.8 \mathrm{~Hz}$, $2 \mathrm{H}), 8.36(\mathrm{~d}, J=6.4 \mathrm{~Hz}, 1 \mathrm{H}), 8.81(\mathrm{~s}, 1 \mathrm{H}), 9.17(\mathrm{~s}, 1 \mathrm{H})$, $10.22(\mathrm{~s}, 1 \mathrm{H}), 10.77(\mathrm{~s}, 1 \mathrm{H})$; mass $(\mathrm{m} / \mathrm{z})$ : $317.33\left(\mathrm{M}^{+}, 11 \%\right)$, 240.05 (100\%).

(7) N-(4-((4-Chlorophenyl)carbamoyl)phenyl)nicotinamide (7e). Yield: $79 \%$; melting point: $272-274^{\circ} \mathrm{C}$; HPLC purity 98.40\%; IR $v_{\max } / \mathrm{cm}^{-1}: 3325(\mathrm{NH}), 1663,1647(\mathrm{C}=\mathrm{O}) ;{ }^{1} \mathrm{H}$ NMR (DMSO- $d 6,400 \mathrm{MHz}) \delta$ ppm: $7.40(\mathrm{~d}, J=8.4 \mathrm{~Hz}$, $2 \mathrm{H}), 7.59(\mathrm{t}, J=6.4 \mathrm{~Hz}, 1 \mathrm{H}), 7.85(\mathrm{~d}, J=8.4 \mathrm{~Hz}, 2 \mathrm{H}), 7.96$ $(\mathrm{d}, J=8.0 \mathrm{~Hz}, 2 \mathrm{H}), 8.02(\mathrm{~d}, J=8.0 \mathrm{~Hz}, 2 \mathrm{H}), 8.36(\mathrm{~d}, J=7.2$ $\mathrm{Hz}, 1 \mathrm{H}), 8.78(\mathrm{~s}, 1 \mathrm{H}), 9.17(\mathrm{~s}, 1 \mathrm{H}), 10.45(\mathrm{~s}, 1 \mathrm{H}), 10.94(\mathrm{~s}$, $1 \mathrm{H})$; mass $(\mathrm{m} / \mathrm{z}): 351.12\left(\mathrm{M}^{+}, 26 \%\right), 352.19\left(\mathrm{M}^{+1}, 8 \%\right), 197$ $(100 \%)$.

(8) N-(4-(o-Tolylcarbamoyl)phenyl)nicotinamide (7f). Yield: $88 \%$; melting point: $194-197^{\circ} \mathrm{C}$; HPLC purity $97.21 \%$; IR $v_{\max } / \mathrm{cm}^{-1}: 3275,3252(\mathrm{NH}), 1681,1643(\mathrm{C}=\mathrm{O}) ;{ }^{1} \mathrm{H}$ NMR (DMSO-d6, $400 \mathrm{MHz}) \delta \mathrm{ppm}$ : $2.26(\mathrm{~s}, 3 \mathrm{H}), 7.18(\mathrm{dt}, J=7.2$ , $7.2 \mathrm{~Hz}, 1 \mathrm{H}), 7.23(\mathrm{dt}, J=7.6,7.6 \mathrm{~Hz}, 1 \mathrm{H}), 7.28(\mathrm{dd}, J=$ $7.6,7.2 \mathrm{~Hz}, 1 \mathrm{H}), 7.35(\mathrm{dd}, J=7.2,8.0 \mathrm{~Hz}, 1 \mathrm{H}), 7.59$ (dd, $J$ $=6.8,8.0 \mathrm{~Hz}, 1 \mathrm{H}), 7.95(\mathrm{~d}, J=8.8 \mathrm{~Hz}, 2 \mathrm{H}), 8.03(\mathrm{~d}, J=8.8$ $\mathrm{Hz}, 2 \mathrm{H}), 8.34(\mathrm{~d}, J=8.0 \mathrm{~Hz}, 1 \mathrm{H}), 8.79(\mathrm{~s}, 1 \mathrm{H}), 9.16(\mathrm{~s}, 1 \mathrm{H})$, $9.86(\mathrm{~s}, 1 \mathrm{H}), 10.76(\mathrm{~s}, 1 \mathrm{H}) ;{ }^{13} \mathrm{C}$ NMR (DMSO-d6) $\delta(\mathrm{ppm})$ : 
$18.44,120.04$ (2C), 124.03, 126.39, 126.47, 127.10, 128.97 (2C), 130.05, 130.78, 130.86, 134.19, 136.09, 136.98, 142.31, $149.27,152.79,164.90,165.16$.

(9) N-(4-((2,4-Dichlorophenyl)carbamoyl)phenyl)nicotinamide (7g). Yield: $80 \%$; melting point: $189-192^{\circ} \mathrm{C}$; HPLC purity 97.56\%; IR $v_{\max } / \mathrm{cm}^{-1}: 3352,3313(\mathrm{NH}), 1681(\mathrm{C}=$ $\mathrm{O}) ;{ }^{1} \mathrm{H}$ NMR (DMSO-d6, $\left.400 \mathrm{MHz}\right) \delta$ ppm: $7.18(\mathrm{~d}, J=8.0$ $\mathrm{Hz}, 1 \mathrm{H}), 7.37$ (d, $J=8.0 \mathrm{~Hz}, 1 \mathrm{H}), 7.60(\mathrm{~d}, J=8.4 \mathrm{~Hz}, 2 \mathrm{H})$, $7.97(\mathrm{~d}, J=7.6 \mathrm{~Hz}, 2 \mathrm{H}), 8.04(\mathrm{~d}, J=7.6 \mathrm{~Hz}, 2 \mathrm{H}), 8.37$ (d, $J$ $=7.6 \mathrm{~Hz}, 1 \mathrm{H}), 8.82(\mathrm{~s}, 1 \mathrm{H}), 9.18(\mathrm{~s}, 1 \mathrm{H}), 10.10(\mathrm{~s}, 1 \mathrm{H})$, $10.79(\mathrm{~s}, 1 \mathrm{H})$; mass $(\mathrm{m} / \mathrm{z}): 386.79\left(\mathrm{M}^{+}, 41 \%\right), 388.14\left(\mathrm{M}^{+2}\right.$, 17\%), 199 (100\%).

(10) N-(4-(m-Tolylcarbamoyl)phenyl)nicotinamide (7h). Yield: $85 \%$; melting point: $217-219^{\circ} \mathrm{C}$; HPLC purity $95.48 \%$; IR $v_{\max }$ $/ \mathrm{cm}^{-1}: 3348(\mathrm{NH}), 1670,1651(\mathrm{C}=\mathrm{O}) ;{ }^{1} \mathrm{H}$ NMR (DMSO-d6, $400 \mathrm{MHz}) \delta$ ppm: $2.32(\mathrm{~s}, 3 \mathrm{H}), 6.91(\mathrm{~d}, J=7.6 \mathrm{~Hz}, 1 \mathrm{H}), 7.22$ $(\mathrm{t}, J=8.0 \mathrm{~Hz}, 1 \mathrm{H}), 7.58(\mathrm{~m}, 2 \mathrm{H}), 7.66(\mathrm{~s}, 1 \mathrm{H}), 7.96(\mathrm{~d}, J=$ $8.4 \mathrm{~Hz}, 2 \mathrm{H}), 8.02(\mathrm{~d}, J=8.4 \mathrm{~Hz}, 2 \mathrm{H}), 8.34(\mathrm{~d}, J=8.0 \mathrm{~Hz}$, $1 \mathrm{H}), 8.80$ (s, 1H), 9.17 (s, 1H), $10.14(\mathrm{~s}, 1 \mathrm{H}), 10.75$ (s, 1H); mass $(\mathrm{m} / z): 331.34\left(\mathrm{M}^{+}, 14 \%\right), 123(100 \%)$.

(11) N-(4-((2-Nitrophenyl)carbamoyl)phenyl)nicotinamide (7i). Yield: 87\%; melting point: $198-201^{\circ} \mathrm{C}$; HPLC purity 95.60\%; IR $v_{\max } / \mathrm{cm}^{-1}: 3329,3190(\mathrm{NH}), 1670(\mathrm{C}=\mathrm{O}), 1597$, $1338\left(\mathrm{NO}_{2}\right) ;{ }^{1} \mathrm{H}$ NMR (DMSO-d6, $\left.400 \mathrm{MHz}\right) \delta$ ppm: 7.43 $(\mathrm{t}, J=8.4 \mathrm{~Hz}, 1 \mathrm{H}), 7.61(\mathrm{~d}, J=8.0 \mathrm{~Hz}, 1 \mathrm{H}), 7.77(\mathrm{~d}, J=7.6$ $\mathrm{Hz}, 2 \mathrm{H}), 8.01(\mathrm{~m}, 5 \mathrm{H}), 8.34(\mathrm{~d}, J=7.2 \mathrm{~Hz}, 1 \mathrm{H}), 8.80$ (s, $1 \mathrm{H}), 9.16(\mathrm{~s}, 1 \mathrm{H}), 10.76(\mathrm{~s}, 1 \mathrm{H}), 10.79(\mathrm{~s}, 1 \mathrm{H}) ;{ }^{13} \mathrm{C} \mathrm{NMR}$ (DMSO-d6) $\delta$ (ppm): 120.15 (2C), 124.04, 125.47, 125.88, $126.27,128.94,129.19$ (2C), 130.79, 132.19, 134.52, 136.11, $142.97,143.22,149.28,152.85,164.99,165.17$.

(12) N-(4-(p-Tolylcarbamoyl)phenyl)nicotinamide (7j). Yield: 76\%; melting point: $219-222^{\circ} \mathrm{C}$; HPLC purity $96.21 \%$; IR $v_{\max } / \mathrm{cm}^{-1}: 3348(\mathrm{NH}), \quad 1662,1647 \quad(\mathrm{C}=\mathrm{O}) ;{ }^{1} \mathrm{H} \quad \mathrm{NMR}$ (DMSO-d6, $400 \mathrm{MHz}) \delta$ ppm: 2.29 (s, 3H), 7.15 (d, J=8.0 $\mathrm{Hz}, 2 \mathrm{H}), 7.58(\mathrm{~d}, J=7.2 \mathrm{~Hz}, 1 \mathrm{H}), 7.67(\mathrm{~d}, J=8.0 \mathrm{~Hz}, 2 \mathrm{H})$, $7.95(\mathrm{~d}, J=8.4 \mathrm{~Hz}, 2 \mathrm{H}), 8.01(\mathrm{~d}, J=8.4 \mathrm{~Hz}, 2 \mathrm{H}), 8.35(\mathrm{~d}, J$ $=7.6 \mathrm{~Hz}, 1 \mathrm{H}), 8.79(\mathrm{~s}, 1 \mathrm{H}), 9.16(\mathrm{~s}, 1 \mathrm{H}), 10.17(\mathrm{~s}, 1 \mathrm{H})$, $10.83(\mathrm{~s}, 1 \mathrm{H})$; mass $(\mathrm{m} / z)$ : $332\left(\mathrm{M}^{+}, 17 \%\right), 241(100 \%)$.

(13) N-(4-((2,4-Dimethylphenyl)carbamoyl)phenyl)nicotinamide (7k). Yield: $85 \%$; melting point: $254-256^{\circ} \mathrm{C}$; IR $v_{\max }$ $/ \mathrm{cm}^{-1}$ : 3278, $3182(\mathrm{NH}), 1665,1635(\mathrm{C}=\mathrm{O}) ;{ }^{1} \mathrm{H}$ NMR (DMSO-d6, $400 \mathrm{MHz}) \delta$ ppm: $2.21(\mathrm{~s}, 6 \mathrm{H}), 7.14(\mathrm{~s}, 3 \mathrm{H})$, $7.59(\mathrm{t}, J=6.0 \mathrm{~Hz}, 1 \mathrm{H}), 7.95(\mathrm{~d}, J=8.0 \mathrm{~Hz}, 2 \mathrm{H}), 8.05(\mathrm{~d}, J$ $=8.0 \mathrm{~Hz}, 2 \mathrm{H}), 8.35(\mathrm{~d}, J=7.6 \mathrm{~Hz}, 1 \mathrm{H}), 8.80(\mathrm{~s}, 1 \mathrm{H}), 9.17$ (s, 1H), $9.75(\mathrm{~s}, 1 \mathrm{H}), 10.75(\mathrm{~s}, 1 \mathrm{H}) ;{ }^{13} \mathrm{C}$ NMR (DMSO-d6) $\delta$ (ppm): 18.15, 18.59, 120.11 (2C), 124.03, 127.11, 128.19 (2C), 128.84 (2C), 129.96, 130.83, 135.89, 136.09, 136.15 (2C), 142.21, 149.26, 152.80, 164.87, 164.93; mass $(\mathrm{m} / \mathrm{z})$ : $345.11\left(\mathrm{M}^{+}, 27 \%\right), 240(100 \%)$.

(14) N-(4-((4-Fluorophenyl)carbamoyl)phenyl)nicotinamide (7l). Yield: $81 \%$; melting point: $259-261^{\circ} \mathrm{C}$; HPLC purity 96.21\%; IR $v_{\max } / \mathrm{cm}^{-1}$ : $3340(\mathrm{NH}), 1668,1643(\mathrm{C}=\mathrm{O}) ;{ }^{1} \mathrm{H}$ NMR (DMSO- $d 6,400 \mathrm{MHz}) \delta$ ppm: $7.40(\mathrm{dt}, J=6.8$,
$6.4 \mathrm{~Hz}, 2 \mathrm{H}), 7.59(\mathrm{dd}, J=7.6,8.0 \mathrm{~Hz}, 1 \mathrm{H}), 7.82(\mathrm{dt}, J=7.6$, $8.0 \mathrm{~Hz}, 2 \mathrm{H}), 7.95(\mathrm{~d}, J=8.0 \mathrm{~Hz}, 2 \mathrm{H}), 8.01(\mathrm{~d}, J=8.0 \mathrm{~Hz}$, $2 \mathrm{H}), 8.33(\mathrm{~d}, J=8.0 \mathrm{~Hz}, 1 \mathrm{H}), 8.79(\mathrm{~s}, 1 \mathrm{H}), 9.15(\mathrm{~s}, 1 \mathrm{H})$, 10.28 (s, 1H), 10.74 (s, 1H).

4.1.2. N-(4-(2-(2,2,2-Trifluoroacetyl)hydrazine-1carbonyl)phenyl)nicotinamide (10). N-(4-(Hydrazinecarbonyl)phenyl)nicotinamide $9(0.256 \mathrm{~g}, 0.001 \mathrm{~mol})$ in DCM $(25 \mathrm{ml})$ was stirred at room temperature with trifluoroacetic anhydride $(0.001 \mathrm{~mol})$ for $4 \mathrm{~h}$. The formed precipitate was then collected and crystallized from ethanol.

Yield: $85 \%$; melting point: $287-290^{\circ} \mathrm{C}$; HPLC purity 96.38\%; IR $v_{\max } / \mathrm{cm}^{-1}: 3348,3232(\mathrm{NH}), 1751,1662(\mathrm{C}=$ $\mathrm{O}) ;{ }^{1} \mathrm{H}$ NMR (DMSO-d6, $\left.400 \mathrm{MHz}\right) \delta \mathrm{ppm}: 7.59(\mathrm{dd}, J$ $=8.0,8.0 \mathrm{~Hz}, 1 \mathrm{H}), 7.94(\mathrm{~d}, J=8.4 \mathrm{~Hz}, 2 \mathrm{H}), 8.00(\mathrm{~d}, J=$ $8.4 \mathrm{~Hz}, 2 \mathrm{H}), 8.32(\mathrm{~d}, J=8.0 \mathrm{~Hz}, 1 \mathrm{H}), 8.79$ (s, $1 \mathrm{H}), 9.14$ (s, 1H), $10.75(\mathrm{~s}, 2 \mathrm{H}), 11.75(\mathrm{~s}, 1 \mathrm{H}) ;{ }^{13} \mathrm{C}$ NMR (DMSOd6) $\delta$ (ppm): 120.15 (2C), 124.04, 127.18, 128.89 (2C), $130.81,136.10$ (2C), 142.91, 149.25 (2C), 152.83, 164.99, 165.13 .

4.1.3. General Procedure for Synthesis of Compounds 11a-h. A mixture of $\mathrm{N}$-(4-(hydrazinecarbonyl)phenyl)nicotinamide $9(0.256 \mathrm{~g}, 0.001 \mathrm{~mol})$ and the appropriate aromatic aldehyde (0.001 mol), namely, 4-fluorobenzaldehyde, benzaldehyde, 4nitrobenzaldehyde, 4-methoxybenzaldehyde, 2,6-dichlorobenzaldehyde, 2-chlorobenzaldehyde, 4-(dimethylamino)benzaldehyde, or 4-hydroxybenzaldehyde $(0.001 \mathrm{~mol})$ was refluxed in absolute ethanol $(30 \mathrm{ml})$ containing a few drops of glacial acetic acid for $2 \mathrm{~h}$. After reaction completion, the mixture was cooled to room temperature, and the formed precipitate was then filtered, dried, and recrystallized from ethanol.

(1) (E)-N-(4-(2-(4-Fluorobenzylidene)hydrazine-1-carbonyl)phenyl)-nicotinamide (11a). Yield: 85\%; melting point: 263$265^{\circ} \mathrm{C}$; IR $v_{\max } / \mathrm{cm}^{-1}: 3375,3242(\mathrm{NH}), 1664(\mathrm{C}=\mathrm{O}) ;{ }^{1} \mathrm{H}$ NMR (DMSO- $d 6,400 \mathrm{MHz}) \delta \mathrm{ppm}: 7.32(\mathrm{~d}, J=8.0 \mathrm{~Hz}$, $2 \mathrm{H}), 7.59(\mathrm{dd}, J=6.8,7.2 \mathrm{~Hz}, 1 \mathrm{H}), 7.81(\mathrm{~d}, J=8.0 \mathrm{~Hz}$, 2H), $7.96(\mathrm{~m}, 4 \mathrm{H}), 8.33(\mathrm{~d}, J=8.0 \mathrm{~Hz}, 1 \mathrm{H}), 8.48(\mathrm{~s}, 1 \mathrm{H})$, $8.80(\mathrm{~s}, 1 \mathrm{H}), 9.15(\mathrm{~s}, 1 \mathrm{H}), 10.74(\mathrm{~s}, 1 \mathrm{H}), 11.86(\mathrm{~s}, 1 \mathrm{H})$; ${ }^{13} \mathrm{C}$ NMR (DMSO-d6) $\delta$ (ppm): 116.29 (2C), 120.05 (2C), 124.03 (2C), 128.99 (2C), 129.66, 130.82, 136.07 (2C), $142.50,146.80,149.25$ (2C), 152.82, 162.99, 164.79, 164.91 .

(2) (E)-N-(4-(2-Benzylidenehydrazine-1-carbonyl)phenyl)-nicotinamide (11b). Yield: $81 \%$; melting point: $260-262^{\circ} \mathrm{C}$; HPLC purity 96.50\%; IR $v_{\max } / \mathrm{cm}^{-1}: 3332,3259(\mathrm{NH}), 1647(\mathrm{C}=\mathrm{O})$; ${ }^{1} \mathrm{H}$ NMR (DMSO-d6, $\left.400 \mathrm{MHz}\right) \delta$ ppm: $7.47(\mathrm{~d}, J=6.4 \mathrm{~Hz}$, $2 \mathrm{H}), 7.49(\mathrm{~d}, J=7.6 \mathrm{~Hz}, 1 \mathrm{H}), 7.59(\mathrm{dd}, J=8.0,8.0 \mathrm{~Hz}, 1 \mathrm{H})$, $7.81(\mathrm{~d}, J=6.8 \mathrm{~Hz}, 2 \mathrm{H}), 7.94(\mathrm{~d}, J=8.8 \mathrm{~Hz}, 2 \mathrm{H}), 7.97$ (d, $J=$ $8.8 \mathrm{~Hz}, 2 \mathrm{H}), 8.32$ (d, J = 8.0 Hz, 1H), 8.48 (s, $1 \mathrm{H}), 8.79$ (s, $1 \mathrm{H}), 9.15(\mathrm{~s}, 1 \mathrm{H}), 10.74(\mathrm{~s}, 1 \mathrm{H}), 11.85(\mathrm{~s}, 1 \mathrm{H}) ;{ }^{13} \mathrm{C} \mathrm{NMR}$ (DMSO-d6) $\delta$ (ppm): 120.07 (2C), 124.06 (2C), 127.56 (2C), $129.00,129.35$ (2C), 130.82, 134.84, 136.09 (2C), 142.84, $147.98,149.23(2 \mathrm{C}), 152.82,163.02,164.93$.

(3) (E)-N-(4-(2-(4-Nitrobenzylidene)hydrazine-1-carbonyl)phenyl)-nicotinamide (11c). Yield: 89\%; melting point: 291- 
$293^{\circ} \mathrm{C}$; HPLC purity $96.62 \%$; IR $v_{\max } / \mathrm{cm}^{-1}: 3360,3294(\mathrm{NH})$, $1670(\mathrm{C}=\mathrm{O}) ;{ }^{1} \mathrm{H}$ NMR (DMSO-d6, $\left.400 \mathrm{MHz}\right) \delta \mathrm{ppm}: 7.60$ $(\mathrm{dd}, J=8.0,7.2 \mathrm{~Hz}, 1 \mathrm{H}), 7.85(\mathrm{~s}, 1 \mathrm{H}), 7.95(\mathrm{~d}, J=8.4 \mathrm{~Hz}$, 2H), $7.99(\mathrm{~s}, 1 \mathrm{H}), 8.01(\mathrm{~d}, J=8.4 \mathrm{~Hz}, 2 \mathrm{H}), 8.33(\mathrm{~m}, 3 \mathrm{H}), 8.57$ (s, 1H), 8.80 (s, 1H), 9.15 (s, 1H), $10.75(\mathrm{~s}, 1 \mathrm{H}), 12.15$ (s, $1 \mathrm{H})$; mass $(\mathrm{m} / \mathrm{z})$ : $390.18\left(\mathrm{M}^{+}, 21 \%\right), 197(100 \%)$.

(4) (E)-N-(4-(2-(4-Methoxybenzylidene)hydrazine-1-carbonyl)phenyl)-nicotinamide (11d). Yield: 78\%; melting point: $264-267^{\circ} \mathrm{C}$; HPLC purity $97.33 \%$; IR $v_{\max } / \mathrm{cm}^{-1}: 3325,3251$ (NH), 1660, $1643(\mathrm{C}=\mathrm{O}) ;{ }^{1} \mathrm{H}$ NMR (DMSO-d6, $\left.400 \mathrm{MHz}\right) \delta$ ppm: 3.82 (s, 3H), 7.03 (d, $J=8.4 \mathrm{~Hz}, 2 \mathrm{H}), 7.59$ (dd, $J=7.6$, $7.6 \mathrm{~Hz}, 1 \mathrm{H}), 7.68(\mathrm{~d}, J=8.4 \mathrm{~Hz}, 2 \mathrm{H}), 7.93(\mathrm{~d}, J=8.8 \mathrm{~Hz}, 2 \mathrm{H})$, $7.96(\mathrm{~d}, J=8.8 \mathrm{~Hz}, 2 \mathrm{H}), 8.32(\mathrm{~d}, J=8.0 \mathrm{~Hz}, 1 \mathrm{H}), 8.42(\mathrm{~s}, 1 \mathrm{H})$, $8.79(\mathrm{~s}, 1 \mathrm{H}), 9.14(\mathrm{~s}, 1 \mathrm{H}), 10.73(\mathrm{~s}, 1 \mathrm{H}), 11.72(\mathrm{~s}, 1 \mathrm{H}) ;{ }^{13} \mathrm{C}$ NMR (DMSO-d6) $\delta$ (ppm): 55.77, 114.82 (2C), 120.06 (2C), 124.05 (2C), 127.04, 128.92 (2C), 130.82, 136.08 (2C), 142.37, $147.89,149.23$ (2C), 152.81, 161.28, 162.85, 164.91 .

(5) (E)-N-(4-(2-(2,6-Dichlorobenzylidene)hydrazine-1-carbonyl)phenyl)-nicotinamide (11e). Yield: 74\%; melting point: 283-285 $\mathrm{C}$; HPLC purity $96.77 \%$; IR $v_{\max } / \mathrm{cm}^{-1}$ : IR (KBr) $\mathrm{cm}^{-1}$ : 3294, $3170(\mathrm{NH}), 1651(\mathrm{C}=\mathrm{O}) ;{ }^{1} \mathrm{H}$ NMR (DMSO-d6, $400 \mathrm{MHz}) \delta \mathrm{ppm}: 7.44(\mathrm{t}, J=8.0 \mathrm{~Hz}, 1 \mathrm{H}), 7.59(\mathrm{~m}, 3 \mathrm{H})$, $7.94(\mathrm{~d}, J=8.4 \mathrm{~Hz}, 2 \mathrm{H}), 8.00(\mathrm{~d}, J=8.4 \mathrm{~Hz}, 2 \mathrm{H}), 8.33(\mathrm{~d}, J$ $=7.6 \mathrm{~Hz}, 1 \mathrm{H}), 8.69(\mathrm{~s}, 1 \mathrm{H}), 8.79(\mathrm{~s}, 1 \mathrm{H}), 9.15(\mathrm{~s}, 1 \mathrm{H})$, $10.75(\mathrm{~s}, 1 \mathrm{H}), 12.14(\mathrm{~s}, 1 \mathrm{H})$; mass $(\mathrm{m} / \mathrm{z}): 412.71\left(\mathrm{M}^{+}, 29 \%\right)$, $414.02\left(\mathrm{M}^{+1}, 17 \%\right), 344(100 \%)$.

(6) (E)-N-(4-(2-(2-Chlorobenzylidene)hydrazine-1-carbonyl)phenyl)-nicotinamide (11f). Yield: 77\%; melting point: 191$193^{\circ} \mathrm{C}$; HPLC purity $97.99 \%$; IR $v_{\max } / \mathrm{cm}^{-1}: 3248,3178$ $(\mathrm{NH}), 1674,1635(\mathrm{C}=\mathrm{O}) ;{ }^{1} \mathrm{H}$ NMR (DMSO-d6, $\left.400 \mathrm{MHz}\right)$ $\delta$ ppm: $7.44(\mathrm{~m}, 2 \mathrm{H}), 7.54(\mathrm{~m}, 1 \mathrm{H}), 7.59(\mathrm{dd}, J=7.6$, $8.0 \mathrm{~Hz}, 1 \mathrm{H}), 7.95(\mathrm{~d}, J=8.0 \mathrm{~Hz}, 2 \mathrm{H}), 7.99(\mathrm{~d}, J=8.0 \mathrm{~Hz}$, $2 \mathrm{H}), 8.05(\mathrm{~s}, 1 \mathrm{H}), 8.32(\mathrm{~d}, J=8.0 \mathrm{~Hz}, 1 \mathrm{H}), 8.79(\mathrm{~s}, 1 \mathrm{H})$, 8.89 (s, 1H), $9.15(\mathrm{~s}, 1 \mathrm{H}), 10.74(\mathrm{~s}, 1 \mathrm{H}), 12.08(\mathrm{~s}, 1 \mathrm{H})$; mass $(\mathrm{m} / \mathrm{z}): 378.13\left(\mathrm{M}^{+}, 21 \%\right), 379.53\left(\mathrm{M}^{+1}, 8 \%\right), 345(100 \%)$.

(7) (E)-N-(4-(2-(4-(Dimethylamino)benzylidene)hydrazine1-carbonyl)phenyl)-nicotinamide (11g). Yield: 82\%; melting point: $273-275^{\circ} \mathrm{C}$; HPLC purity $97.37 \%$; IR $v_{\max } / \mathrm{cm}^{-1}$ : 3321, $3255(\mathrm{NH}), 1651(\mathrm{C}=\mathrm{O}) ;{ }^{1} \mathrm{H}$ NMR (DMSO-d6, $400 \mathrm{MHz}) \delta \mathrm{ppm}: 2.99(\mathrm{~s}, 6 \mathrm{H}), 6.76(\mathrm{~d}, J=8.4 \mathrm{~Hz}, 2 \mathrm{H})$, $7.55(\mathrm{~d}, J=8.4 \mathrm{~Hz}, 2 \mathrm{H}), 7.59(\mathrm{dd}, J=8.0,7.6 \mathrm{~Hz}, 1 \mathrm{H}), 7.92$ $(\mathrm{d}, J=9.2 \mathrm{~Hz}, 2 \mathrm{H}), 7.95(\mathrm{~d}, J=9.2 \mathrm{~Hz}, 2 \mathrm{H}), 8.33(\mathrm{~s}, 1 \mathrm{H})$, $8.35(\mathrm{t}, J=6.0 \mathrm{~Hz}, 1 \mathrm{H}), 8.79(\mathrm{~s}, 1 \mathrm{H}), 9.15(\mathrm{~s}, 1 \mathrm{H}), 10.72(\mathrm{~s}$, $1 \mathrm{H}), 11.54(\mathrm{~s}, 1 \mathrm{H}) ;{ }^{13} \mathrm{C}$ NMR (DMSO-d6) $\delta(\mathrm{ppm}): 40.26$ (2C), 112.29 (2C), 120.03 (2C), 122.13, 124.04 (2C), 128.89 (2C), 130.84, 136.07 (2C), 142.21, 148.81, 149.24 (2C), $151.95,152.80,162.54,164.87$.

(8) (E)-N-(4-(2-(4-Hydroxybenzylidene)hydrazine-1-carbonyl)phenyl)-nicotinamide (11h). Yield: 72\%; melting point: 256-259 ${ }^{\circ}$ C HPLC purity 97.49\%; IR $v_{\max } / \mathrm{cm}^{-1}: 3340(\mathrm{OH})$, 3267, $3182(\mathrm{NH}), 1671,1643(\mathrm{C}=\mathrm{O})$; ${ }^{1} \mathrm{H}$ NMR (DMSO-d6, $400 \mathrm{MHz}) \delta$ ppm: $6.85(\mathrm{~d}, J=8.4 \mathrm{~Hz}, 2 \mathrm{H}), 7.57(\mathrm{~d}, J=8.4 \mathrm{~Hz}$ , $2 \mathrm{H}), 7.60$ (dd, $J=8.0,8.0 \mathrm{~Hz}, 1 \mathrm{H}), 7.92(\mathrm{~d}, J=8.8 \mathrm{~Hz}, 2 \mathrm{H})$, $7.95(\mathrm{~d}, J=8.8 \mathrm{~Hz}, 2 \mathrm{H}), 8.32(\mathrm{~d}, J=8.0 \mathrm{~Hz}, 1 \mathrm{H}), 8.36(\mathrm{~s}, 1 \mathrm{H})$, $8.79(\mathrm{~s}, 1 \mathrm{H}), 9.14(\mathrm{~s}, 1 \mathrm{H}), 9.97(\mathrm{~s}, 1 \mathrm{H}), 10.72(\mathrm{~s}, 1 \mathrm{H}), 11.63(\mathrm{~s}$, $1 \mathrm{H}) ;{ }^{13} \mathrm{C}$ NMR (DMSO-d6) $\delta$ (ppm): 116.19 (2C), 120.03 (2C), 124.05 (2C), 125.83, 128.88 (2C), 130.83, 136.07 (2C), $142.31,148.28,149.23$ (2C), 152.81, 159.86, 162.72, 164.89 .

4.1.4. General Procedure for Synthesis of Compounds 18a-c. A mixture of the potassium salt $15(0.217 \mathrm{~g}, 0.001 \mathrm{~mol})$ and the appropriate chloroacetanilides $(0.001 \mathrm{~mol})$, namely, 2chloro- $\mathrm{N}$-(4-chlorophenyl)acetamide $17 \mathrm{a}, 2$-chloro- $\mathrm{N}$-phenylacetamide $17 \mathrm{~b}$, or $N$-benzyl-2-chloroacetamide $17 \mathrm{c}$ $(0.001 \mathrm{~mol})$ in dry DMF $(25 \mathrm{ml})$ with a catalytic amount of potassium iodide was heated over a water bath for $4 \mathrm{~h}$. Then, the reaction mixture was cooled, poured into ice water $(50 \mathrm{ml})$, and stirred well for $0.5 \mathrm{~h}$. The residue was filtered off, and the crude product was crystallized from ethanol.

(1) $\mathrm{N}$-(4-Chlorophenyl)-2-((5-(pyridin-3-yl)-1,3,4-oxadiazol2-yl)thio)acetamide (18a). Yield: $72 \%$; melting point: 225 $228^{\circ} \mathrm{C}$; IR $v_{\max } / \mathrm{cm}^{-1}$ : $3271(\mathrm{NH}), 1635(\mathrm{C}=\mathrm{O}) ;{ }^{1} \mathrm{H}$ NMR (DMSO-d6, $400 \mathrm{MHz}) \delta$ ppm: $3.85(\mathrm{~s}, 2 \mathrm{H}), 7.41(\mathrm{~d}, J=8.8$ $\mathrm{Hz}, 2 \mathrm{H}), 7.61(\mathrm{t}, J=8.0 \mathrm{~Hz}, 1 \mathrm{H}), 7.64(\mathrm{~d}, J=8.8 \mathrm{~Hz}, 2 \mathrm{H})$, $8.24(\mathrm{~d}, J=8.0 \mathrm{~Hz}, 1 \mathrm{H}), 8.74(\mathrm{dd}, J=4.8,4.8 \mathrm{~Hz}, 1 \mathrm{H}), 9.07$ $(\mathrm{s}, 1 \mathrm{H}), 10.37(\mathrm{~s}, 1 \mathrm{H})$; mass $(\mathrm{m} / \mathrm{z}): 346.12\left(\mathrm{M}^{+}, 31 \%\right)$, $347.34\left(\mathrm{M}^{+1}, 11 \%\right), 312.51(100 \%)$.

(2) N-Phenyl-2-((5-(pyridin-3-yl)-1,3,4-oxadiazol-2-yl)thio)acetamide (18b). Yield: $72 \%$; melting point: $232-234^{\circ} \mathrm{C}$; IR $v_{\max }$ $/ \mathrm{cm}^{-1}$ : $3209(\mathrm{NH}), 1635(\mathrm{C}=\mathrm{O}) ;{ }^{1} \mathrm{H}$ NMR (DMSO-d6, $400 \mathrm{MHz}) \delta$ ppm: $3.58(\mathrm{~s}, 2 \mathrm{H}), 7.04(\mathrm{t}, J=7.6 \mathrm{~Hz}, 1 \mathrm{H}), 7.38(\mathrm{t}$, $J=7.6 \mathrm{~Hz}, 2 \mathrm{H}), 7.61(\mathrm{t}, J=7.6 \mathrm{~Hz}, 1 \mathrm{H}), 7.63(\mathrm{~d}, J=7.6 \mathrm{~Hz}$, $2 \mathrm{H}), 8.25(\mathrm{~d}, J=8.0 \mathrm{~Hz}, 1 \mathrm{H}), 8.75(\mathrm{dd}, J=4.8,4.8 \mathrm{~Hz}, 1 \mathrm{H})$, $9.08(\mathrm{~s}, 1 \mathrm{H}), 10.90(\mathrm{~s}, 1 \mathrm{H})$; mass $(\mathrm{m} / \mathrm{z}): 312.19\left(\mathrm{M}^{+}, 100 \%\right)$.

(3) N-Benzyl-2-((5-(pyridin-3-yl)-1,3,4-oxadiazol-2-yl)thio)acetamide (18c). Yield: $72 \%$; melting point: $167-169^{\circ} \mathrm{C}$; HPLC purity 96.89\%; IR $v_{\max } / \mathrm{cm}^{-1}: 3205(\mathrm{NH}), 1647(\mathrm{C}=\mathrm{O}) ;{ }^{1} \mathrm{H}$ NMR (DMSO- $d 6,400 \mathrm{MHz}) \delta \mathrm{ppm}: 4.14(\mathrm{~s}, 2 \mathrm{H}), 4.93$ (s, $2 \mathrm{H}), 7.28(\mathrm{t}, J=6.8 \mathrm{~Hz}, 1 \mathrm{H}), 7.35(\mathrm{t}, J=7.2 \mathrm{~Hz}, 2 \mathrm{H}), 7.41$ $(\mathrm{t}, J=7.2 \mathrm{~Hz}, 2 \mathrm{H}), 7.51(\mathrm{t}, J=8.0 \mathrm{~Hz}, 1 \mathrm{H}), 8.18(\mathrm{~d}, J=6.8$ $\mathrm{Hz}, 1 \mathrm{H}), 8.70(\mathrm{~s}, 1 \mathrm{H}), 9.00(\mathrm{~s}, 1 \mathrm{H})$; mass $(\mathrm{m} / \mathrm{z}): 326.71$ $\left(\mathrm{M}^{+}, 29 \%\right), 147$ (100\%).

\subsection{Biological Evaluation}

4.2.1. In Vitro Antiproliferative Activity against MCF-7, HepG-2, and HCT-116. The antiproliferative activity of the synthesized compounds was evaluated using MTT protocol as described [50-52] (Supplementary data (available here)).

4.2.2. In Vitro VEGFR-2 Enzyme Assay Inhibition. The most potent cytotoxic compounds, 5, 7a, 7b, 7l, 10,11c, 11d, 11f, $11 \mathrm{~g}, 18 \mathrm{a}$, and $18 \mathrm{~b}$, were further assessed to determine their inhibitory activities against the VEGFR-2 enzyme according to the protocol described in the Supplementary data.

\subsubsection{Apoptotic Marker Analysis}

(1) Effects on the Levels of Active Caspase-3. Measurement of caspase- 3 levels was evaluated for the most active members 
according to the protocol described by Andersson et al. [53] (Supplementary data).

(2) Effects on Bcl-2 Family Proteins. Bax and Bcl-2 cellular levels were analyzed for the most potent cytotoxic compounds in HepG-2 cells following the reported protocol [54] (Supplementary data).

(3) Cell Cycle Analysis. According to the method described by Léonce et al., the flow cytometric analysis for compound 7 a was performed $[55,56]$ (Supplementary data).

(4) Apoptotic Cell Subpopulation Determination. The annexin-V-FITC assay for compound 7a on HepG-2 cells was performed according to the reported procedure [57-59] (Supplementary data).

4.2.4. Estimation of Human Tumor Necrosis Factor-Alpha (TNF- $\alpha$ ) in HepG-2 Supernatant. The levels of TNF- $\alpha$ in cell culture supernatants were estimated by the ELISA technique according to the reported procedure $[60,61]$.

4.2.5. Vascular Smooth Muscle Cell Culture. VSMCs were isolated and cultured following the reported method [62] (Supplementary data).

4.3. Docking Study. Discovery Studio 2.5 software was used to perform docking and visualization according to the described protocol [63-66] (Supplementary data).

\section{Data Availability}

Data can be found in the supplementary information files.

\section{Conflicts of Interest}

There is no conflict of interest.

\section{Authors' Contributions}

Feng Ran and Wendong Li are both co-first authors and contributed equally to this work.

\section{Acknowledgments}

The authors acknowledge the support of the Nanjing Medical Science and Technology Development Fund Project (YKK18061).

\section{Supplementary Materials}

Supplementary data related to this manuscript is found in a separate file. (Supplementary Materials)

\section{References}

[1] B. B. Hafen and B. Burns, Physiology, Smooth Muscle, StatPearls Publishing LLC, 2018.

[2] R. Ross, "The pathogenesis of atherosclerosis: a perspective for the 1990s," Nature, vol. 362, no. 6423, pp. 801-809, 1993.
[3] F. H. Epstein, V. Fuster, L. Badimon, J. J. Badimon, and J. H. Chesebro, "The pathogenesis of coronary artery disease and the acute coronary syndromes," New England Journal of Medicine, vol. 326, no. 5, pp. 310-318, 1992.

[4] A. Cardús, E. Parisi, C. Gallego, M. Aldea, E. Fernández, and J. M. Valdivielso, "1,25-Dihydroxyvitamin $\mathrm{D}_{3}$ stimulates vascular smooth muscle cell proliferation through a VEGFmediated pathway," Kidney International, vol. 69, no. 8, pp. 1377-1384, 2006.

[5] C. L. Grosskreutz, B. Anand-Apte, C. Dupláa et al., "Vascular Endothelial Growth Factor-Induced Migration of Vascular Smooth Muscle Cells in Vitro," Microvascular Research, vol. 58, no. 2, pp. 128-136, 1999.

[6] Y. Zhao, S. K. Biswas, P. H. McNulty, M. Kozak, J. Y. Jun, and L. Segar, "PDGF-induced vascular smooth muscle cell proliferation is associated with dysregulation of insulin receptor substrates," American Journal of Physiology-Cell Physiology, vol. 300, no. 6, pp. C1375-C1385, 2011.

[7] J. Himmelfarb and L. Couper, "Dipyridamole inhibits PDGFand bFGF-induced vascular smooth muscle cell proliferation," Kidney International, vol. 52, no. 6, pp. 1671-1677, 1997.

[8] F. Jiang, R. Jiang, X. Zhu, X. Zhang, and Z. Zhan, "Genipin inhibits TNF- $\alpha$-induced vascular smooth muscle cell proliferation and migration via induction of HO-1," PLoS One, vol. 8, no. 8, article e74826, 2013.

[9] H. Loppnow and P. Libby, "Proliferating or interleukin 1activated human vascular smooth muscle cells secrete copious interleukin 6," The Journal of Clinical Investigation, vol. 85, no. 3, pp. 731-738, 1990.

[10] Y.-X. Chen, Y. Nakashima, K. Tanaka, S. Shiraishi, K. Nakagawa, and K. Sueishi, "Immunohistochemical expression of vascular endothelial growth factor/vascular permeability factor in atherosclerotic intimas of human coronary arteries," Arteriosclerosis, Thrombosis, and Vascular Biology, vol. 19, no. 1, pp. 131-139, 1999.

[11] J. Folkman, "Angiogenesis in cancer, vascular, rheumatoid and other disease," Nature Medicine, vol. 1, no. 1, pp. 2730, 1995.

[12] R. S. Kerbel, “Tumor angiogenesis: past, present and the near future," Carcinogenesis, vol. 21, no. 3, pp. 505-515, 2000.

[13] K. el-Adl, A. G. A. el-Helby, R. R. Ayyad et al., "Design, synthesis, and anti-proliferative evaluation of new quinazolin4(3H)-ones as potential VEGFR-2 inhibitors," Bioorganic \& Medicinal Chemistry, vol. 29, article 115872, 2021.

[14] J. Folkman, "Angiogenesis: an organizing principle for drug discovery?," Nature Reviews Drug Discovery, vol. 6, no. 4, pp. 273-286, 2007.

[15] Y. Yang, L. Shi, Y. Zhou, H. Q. Li, Z. W. Zhu, and H. L. Zhu, "Design, synthesis and biological evaluation of quinoline amide derivatives as novel VEGFR-2 inhibitors," Bioorganic \& Medicinal Chemistry Letters, vol. 20, no. 22, pp. 66536656, 2010.

[16] I. H. Eissa, A. G. A. el-Helby, H. A. Mahdy et al., "Discovery of new quinazolin-4(3H)-ones as VEGFR-2 inhibitors: Design, synthesis, and anti-proliferative evaluation," Bioorganic Chemistry, vol. 105, article 104380, 2020.

[17] H. A. Mahdy, M. K. Ibrahim, A. M. Metwaly et al., "Design, synthesis, molecular modeling, in vivo studies and anticancer evaluation of quinazolin-4(3H)-one derivatives as potential VEGFR-2 inhibitors and apoptosis inducers," Bioorganic Chemistry, vol. 94, article 103422, 2020. 
[18] A. G. A. el-Helby, H. Sakr, I. H. Eissa, A. A. al-Karmalawy, and K. el-Adl, "Benzoxazole/benzothiazole-derived VEGFR-2 inhibitors: design, synthesis, molecular docking, and anticancer evaluations," Archiv der Pharmazie, vol. 352, no. 12, article 1900178, 2019.

[19] K. S. Bhullar, N. O. Lagarón, E. M. McGowan et al., "Kinasetargeted cancer therapies: progress, challenges and future directions," Molecular Cancer, vol. 17, no. 1, pp. 1-20, 2018.

[20] H.-T. Zhong, Y.-Z. Yu, and C. Velasco, Molecular Insights Probing Bismurrayaquinone $A$ as an Angiogenesis Inhibitor Via Inhibition of VEGFR-2 Kinase Domain, 2011.

[21] R. Lugano, M. Ramachandran, and A. Dimberg, "Tumor angiogenesis: causes, consequences, challenges and opportunities," Cellular and Molecular Life Sciences, vol. 77, no. 9, pp. 1745-1770, 2020.

[22] T. Hunter, "The role of tyrosine phosphorylation in cell growth and disease," Harvey Lectures, vol. 94, pp. 81-119, 1998.

[23] S. J. Modi and V. M. Kulkarni, "Vascular endothelial growth factor receptor (VEGFR-2)/KDR inhibitors: medicinal chemistry perspective," Medicine in Drug Discovery, vol. 2, article 100009, 2019.

[24] P. Traxler and P. Furet, "Strategies toward the design of novel and selective protein tyrosine kinase inhibitors," Pharmacology and Therapeutics, vol. 82, no. 2-3, pp. 195-206, 1999.

[25] N. S. Gray, L. Wodicka, A. M. Thunnissen et al., "Exploiting chemical libraries, structure, and genomics in the search for kinase inhibitors," Science, vol. 281, no. 5376, pp. 533-538, 1998.

[26] J. G. Cumming, C. L. McKenzie, S. G. Bowden et al., "Novel, potent and selective anilinoquinazoline and anilinopyrimidine inhibitors of p38 MAP kinase," Bioorganic \& Medicinal Chemistry Letters, vol. 14, no. 21, pp. 5389-5394, 2004.

[27] S. R. Hubbard, L. Wei, and W. A. Hendrickson, "Crystal structure of the tyrosine kinase domain of the human insulin receptor," Nature, vol. 372, no. 6508, pp. 746-754, 1994.

[28] N. M. Heron, M. Anderson, D. P. Blowers et al., "SAR and inhibitor complex structure determination of a novel class of potent and specific Aurora kinase inhibitors," Bioorganic \& Medicinal Chemistry Letters, vol. 16, no. 5, pp. 1320-1323, 2006.

[29] F. H. Jung, G. Pasquet, C. Lambert-van der Brempt et al., "Discovery of novel and potent thiazoloquinazolines as selective Aurora A and B kinase inhibitors," Journal of Medicinal Chemistry, vol. 49, no. 3, pp. 955-970, 2006.

[30] Y. Dai, Y. Guo, R. R. Frey et al., “Thienopyrimidine ureas as novel and potent multitargeted receptor tyrosine kinase inhibitors," Journal of Medicinal Chemistry, vol. 48, no. 19, pp. 6066-6083, 2005.

[31] I. H. Eissa, M. K. Ibrahim, A. M. Metwaly et al., "Design, molecular docking, in vitro, and in vivo studies of new quinazolin-4(3H)-ones as VEGFR-2 inhibitors with potential activity against hepatocellular carcinoma," Bioorganic Chemistry, no. article 104532, 2021.

[32] A. Heine, S. A. E. Held, A. Bringmann, T. A. W. Holderried, and P. Brossart, "Immunomodulatory effects of antiangiogenic drugs," Leukemia, vol. 25, no. 6, pp. 899-905, 2011.

[33] E. Y. Woo, H. Yeh, C. S. Chu et al., "Cutting edge: regulatory T cells from lung cancer patients directly inhibit autologous $\mathrm{T}$ cell proliferation," The Journal of Immunology, vol. 168, no. 9, pp. 4272-4276, 2002.
[34] T. J. Curiel, G. Coukos, L. Zou et al., "Specific recruitment of regulatory $\mathrm{T}$ cells in ovarian carcinoma fosters immune privilege and predicts reduced survival," Nature Medicine, vol. 10, no. 9, pp. 942-949, 2004.

[35] J. Shimizu, S. Yamazaki, and S. Sakaguchi, "Induction of tumor immunity by removing CD25+ CD4+ T cells: a common basis between tumor immunity and autoimmunity," The Journal of Immunology, vol. 163, no. 10, pp. 5211-5218, 1999.

[36] J. S. Ko, A. H. Zea, B. I. Rini et al., "Sunitinib mediates reversal of myeloid-derived suppressor cell accumulation in renal cell carcinoma patients," Clinical Cancer Research, vol. 15, no. 6, pp. 2148-2157, 2009.

[37] J. Ozao-Choy, G. Ma, J. Kao et al., "The novel role of tyrosine kinase inhibitor in the reversal of immune suppression and modulation of tumor microenvironment for immune-based cancer therapies," Cancer Research, vol. 69, no. 6, pp. 25142522, 2009.

[38] J. Folkman, "Angiogenesis," Annual Review of Medicine, vol. 57, pp. 1-18, 2006.

[39] P. A. D'Amore and D. T. Shima, “Tumor angiogenesis: a physiological process or genetically determined?" Cancer and Metastasis Reviews, vol. 15, no. 2, pp. 205-212, 1996.

[40] P. Sini, L. Wyder, C. Schnell et al., "The antitumor and antiangiogenic activity of vascular endothelial growth factor receptor inhibition is potentiated by ErbB1 blockade," Clinical Cancer Research, vol. 11, no. 12, pp. 4521-4532, 2005.

[41] A. G. A. el-Helby, H. Sakr, I. H. Eissa, H. Abulkhair, A. A. alKarmalawy, and K. el-Adl, "Design, synthesis, molecular docking, and anticancer activity of benzoxazole derivatives as VEGFR-2 inhibitors," Archiv der Pharmazie, vol. 352, no. 10, article 1900113, 2019.

[42] U. Bhanushali et al., "Design, synthesis and evaluation of 5pyridin-4-yl-2-thioxo-[1,3,4] oxadiazol-3-yl derivatives as anti-angiogenic agents targeting VEGFR-2," Anti-Cancer Agents in Medicinal Chemistry (Formerly Current Medicinal Chemistry-Anti-Cancer Agents), vol. 17, no. 1, pp. 67-74, 2017.

[43] A. Kumar, S. S. D’Souza, S. R. Mysore Nagaraj, S. L. Gaonkar, B. P. Salimath, and K. M. L. Rai, "Antiangiogenic and antiproliferative effects of substituted-1,3,4-oxadiazole derivatives is mediated by down regulation of VEGF and inhibition of translocation of HIF- $1 \alpha$ in Ehrlich ascites tumor cells," Cancer Chemotherapy and Pharmacology, vol. 64, no. 6, pp. 1221-1233, 2009.

[44] F. Qiao, Y. Yin, Y. N. Shen et al., "Synthesis, molecular modeling, and biological evaluation of quinazoline derivatives containing the 1,3,4-oxadiazole scaffold as novel inhibitors of VEGFR2," RSC Advances, vol. 5, no. 26, pp. 19914-19923, 2015.

[45] M. Ibrahim, M. S. Taghour, A. M. Metwaly et al., "Design, synthesis, molecular modeling and anti-proliferative evaluation of novel quinoxaline derivatives as potential DNA intercalators and topoisomerase II inhibitors," European Journal of Medicinal Chemistry, vol. 155, pp. 117-134, 2018.

[46] K. el-Adl, A. G. A. el-Helby, H. Sakr, and A. Elwan, "Design, synthesis, molecular docking and anti-proliferative evaluations of $[1,2,4]$ triazolo[ $4,3-a]$ quinoxaline derivatives as DNA intercalators and Topoisomerase II inhibitors," Bioorganic Chemistry, vol. 105, article 104399, 2020.

[47] A. G. A. el-Helby, H. Sakr, R. R. Ayyad et al., "Design, synthesis, molecular modeling, in vivo studies and anticancer activity evaluation of new phthalazine derivatives as potential DNA 
intercalators and topoisomerase II inhibitors," Bioorganic Chemistry, vol. 103, article 104233, 2020.

[48] S. Sana, V. G. Reddy, S. Bhandari et al., "Exploration of carbamide derived pyrimidine-thioindole conjugates as potential VEGFR-2 inhibitors with anti-angiogenesis effect," European Journal of Medicinal Chemistry, vol. 200, article 112457, 2020.

[49] M. Funakoshi-Tago, T. Shimizu, K. Tago et al., "Celecoxib potently inhibits $\mathrm{TNF} \alpha$-induced nuclear translocation and activation of NF- $\kappa \mathrm{B}$," Biochemical Pharmacology, vol. 76, no. 5, pp. 662-671, 2008.

[50] D. Gerlier and N. Thomasset, "Use of MTT colorimetric assay to measure cell activation," Journal of Immunological Methods, vol. 94, no. 1-2, pp. 57-63, 1986.

[51] F. Denizot and R. Lang, "Rapid colorimetric assay for cell growth and survival: modifications to the tetrazolium dye procedure giving improved sensitivity and reliability," Journal of Immunological Methods, vol. 89, no. 2, pp. 271-277, 1986.

[52] M. I. Thabrew, R. D. Hughes, and I. G. McFarlane, "Screening of hepatoprotective plant components using a HepG2 cell cytotoxicity assay," Journal of Pharmacy and Pharmacology, vol. 49, no. 11, pp. 1132-1135, 2011.

[53] M. Andersson, J. Sjöstrand, A. Petersen, A. K. Honarvar, and J. O. Karlsson, "Caspase and proteasome activity during staurosporin-induced apoptosis in lens epithelial cells," Investigative Ophthalmology and Visual Science, vol. 41, no. 9, pp. 2623-2632, 2000.

[54] E. H. Y. A. Cheng, M. C. Wei, S. Weiler et al., "BCL-2, BCL-X Sequester BH3 Domain-Only Molecules Preventing BAX- and BAK-Mediated Mitochondrial Apoptosis," Molecular Cell, vol. 8, no. 3, pp. 705-711, 2001.

[55] S. Léonce, V. Pérez, S. Lambel et al., "Induction of cyclin E and inhibition of DNA synthesis by the novel acronycine derivative S23906-1 precede the irreversible arrest of tumor cells in S phase leading to apoptosis," Molecular Pharmacology, vol. 60, no. 6, pp. 1383-1391, 2001.

[56] M. M. Alanazi, I. H. Eissa, N. A. Alsaif et al., "Design, synthesis, docking, ADMET studies, and anticancer evaluation of new 3-methylquinoxaline derivatives as VEGFR-2 inhibitors and apoptosis inducers," Journal of Enzyme Inhibition and Medicinal Chemistry, vol. 36, no. 1, pp. 1760-1782, 2021.

[57] K. K.-W. Lo, T. K. M. Lee, J. S. Y. Lau, W. L. Poon, and S. H. Cheng, "Luminescent biological probes derived from ruthenium (II) estradiol polypyridine complexes," Inorganic Chemistry, vol. 47, no. 1, pp. 200-208, 2008.

[58] I. H. Eissa, M. A. Dahab, M. K. Ibrahim et al., "Design and discovery of new antiproliferative 1,2,4-triazin-3(2H)-ones as tubulin polymerization inhibitors targeting colchicine binding site," Bioorganic Chemistry, vol. 112, article 104965, 2021.

[59] M. Hagras, M. A. el Deeb, H. S. A. Elzahabi, E. B. Elkaeed, A. B. M. Mehany, and I. H. Eissa, "Discovery of new quinolines as potent colchicine binding site inhibitors: design, synthesis, docking studies, and anti-proliferative evaluation," Journal of Enzyme Inhibition and Medicinal Chemistry, vol. 36, no. 1, pp. 640-658, 2021.

[60] R. M. Talaat, "Soluble angiogenesis factors in sera of Egyptian patients with hepatitis $\mathrm{C}$ virus infection: correlation with disease severity," Viral Immunology, vol. 23, no. 2, pp. 151-157, 2010.

[61] M. A. el-Zahabi, H. Sakr, K. el-Adl et al., "Design, synthesis, and biological evaluation of new challenging thalidomide analogs as potential anticancer immunomodulatory agents," Bioorganic Chemistry, vol. 104, article 104218, 2020.
[62] N. Endlich, K. Endlich, N. Taesch, and J. J. Helwig, "Culture of vascular smooth muscle cells from small arteries of the rat kidney," Kidney International, vol. 57, no. 6, pp. 2468-2475, 2000.

[63] A. A. Nasser, I. H. Eissa, M. R. Oun et al., "Discovery of new pyrimidine-5-carbonitrile derivatives as anticancer agents targeting EGFRWTand EGFRT790M," Organic \& Biomolecular Chemistry, vol. 18, no. 38, pp. 7608-7634, 2020.

[64] E. M. Abbass, A. K. Khalil, M. M. Mohamed, I. H. Eissa, and A. M. el-Naggar, "Design, efficient synthesis, docking studies, and anticancer evaluation of new quinoxalines as potential intercalative topo II inhibitors and apoptosis inducers," Bioorganic Chemistry, vol. 104, article 104255, 2020.

[65] M. M. Alanazi, H. A. Mahdy, N. A. Alsaif et al., "New bis([1,2,4]triazolo) $\left[4,3-a: 3^{\prime}, 4^{\prime}-c\right]$ quinoxaline derivatives as VEGFR-2 inhibitors and apoptosis inducers: Design, synthesis, in silico studies, and anticancer evaluation," Bioorganic Chemistry, vol. 112, article 104949, 2021.

[66] S. A. el-Metwally, M. M. Abou-el-Regal, I. H. Eissa et al., "Discovery of thieno[2,3- $d]$ pyrimidine-based derivatives as potent VEGFR-2 kinase inhibitors and anti-cancer agents," Bioorganic Chemistry, vol. 112, article 104947, 2021. 